\title{
Copper Bipyridyl Redox Mediators for Dye-Sensitized Solar Cells with High Photovoltage
}

\author{
Yasemin Saygili, ${ }^{\dagger}$ Magnus Söderberg, ${ }^{\ddagger}$ Norman Pellet, ${ }^{\S}$ Fabrizio Giordano, ${ }^{\S}$ Yiming Cao, ${ }^{\S}$ \\ Ana Belen Muñoz-García," Shaik M. Zakeeruddin, ${ }^{\dagger}$ Nick Vlachopoulos, ${ }^{\dagger}$ Michele Pavone, ${ }^{\|}$ \\ Gerrit Boschloo, ${ }^{\perp}$ Ladislav Kavan, ${ }^{\S}, \#$ Jacques-E. Moser, ${ }^{\ddagger}$ Michael Grätzel, ${ }^{\S}$ Anders Hagfeldt, ${ }^{\dagger}$ \\ and Marina Freitag* $*, \dagger, \perp$
}

${ }^{\dagger}$ Laboratory of Photomolecular Science, ${ }^{\ddagger}$ Photochemical Dynamics Group, and ${ }^{\S}$ Laboratory for Photonics and Interfaces, Institute of Chemical Sciences Engineering, École Polytechnique Fédérale de Lausanne, 1015 Lausanne, Switzerland

"Department of Chemical Sciences, University of Naples Federico II, 80126 Naples, Italy

${ }^{\perp}$ Department of Chemistry, Ångström Laboratory, Uppsala University, 75120 Uppsala, Sweden

\#. Heyrovsky Institute of Physical Chemistry, 1823 Prague, Czech Republic

Supporting Information

\begin{abstract}
Redox mediators play a major role determining the photocurrent and the photovoltage in dye-sensitized solar cells (DSCs). To maintain the photocurrent, the reduction of oxidized dye by the redox mediator should be significantly faster than the electron back transfer between $\mathrm{TiO}_{2}$ and the oxidized dye. The driving force for dye regeneration with the redox mediator should be sufficiently low to provide high photovoltages. With the introduction of our new copper complexes as promising redox mediators in DSCs both criteria are satisfied to enhance power conversion efficiencies. In this study, two copper bipyridyl complexes, $\mathrm{Cu}^{(\mathrm{II} / \mathrm{I})}(\mathrm{dmby})_{2} \mathrm{TFSI}_{2 / 1}$ $\left(0.97 \mathrm{~V}\right.$ vs SHE, dmby $=6,6^{\prime}$-dimethyl-2,2' ${ }^{\prime}$-bipyridine $)$ and $\mathrm{Cu}^{(\mathrm{II} / \mathrm{I})}\left(\mathrm{tmby}_{2}\right)_{2} \mathrm{TFSI}_{2 / 1}\left(0.87 \mathrm{~V}\right.$ vs SHE, tmby $=4,4^{\prime}, 6,6^{\prime}$ -

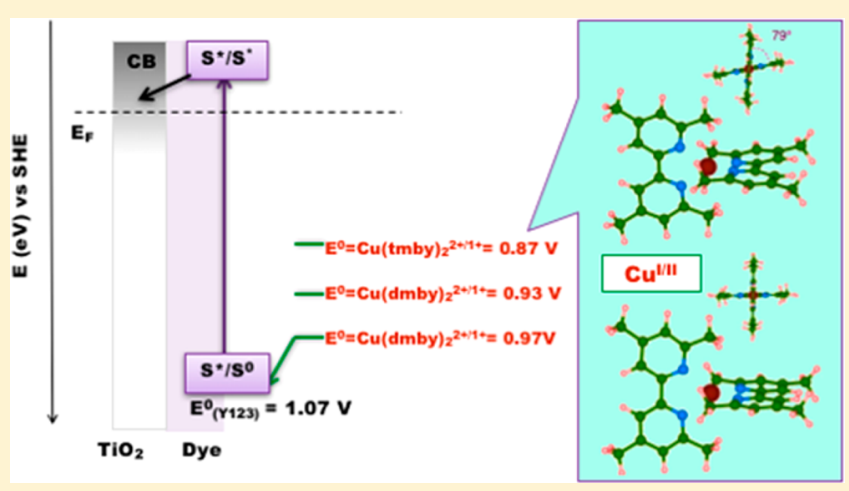
tetramethyl-2,2'-bipyridine), are presented as new redox couples for DSCs. They are compared to previously reported $\mathrm{Cu}^{(\mathrm{II} / \mathrm{I})}(\mathrm{dmp})_{2} \mathrm{TFSI}_{2 / 1}(0.93 \mathrm{~V}$ vs SHE, dmp = bis(2,9-dimethyl-1,10-phenanthroline). Due to the small reorganization energy between $\mathrm{Cu}(\mathrm{I})$ and $\mathrm{Cu}(\mathrm{II})$ species, these copper complexes can sufficiently regenerate the oxidized dye molecules with close to unity yield at driving force potentials as low as $0.1 \mathrm{~V}$. The high photovoltages of over $1.0 \mathrm{~V}$ were achieved by the series of copper complex based redox mediators without compromising photocurrent densities. Despite the small driving forces for dye regeneration, fast and efficient dye regeneration $(2-3 \mu \mathrm{s})$ was observed for both complexes. As another advantage, the electron back transfer (recombination) rates were slower with $\mathrm{Cu}^{(\mathrm{II} / \mathrm{I})}\left(\mathrm{tmby}_{2} \mathrm{TFSI}_{2 / 1}\right.$ as evidenced by longer lifetimes. The solar-toelectrical power conversion efficiencies for $\left[\mathrm{Cu}(\mathrm{tmby})_{2}\right]^{2+/ 1+},\left[\mathrm{Cu}(\mathrm{dmby})_{2}\right]^{2+/ 1+}$, and $\left[\mathrm{Cu}(\mathrm{dmp})_{2}\right]^{2+/ 1+}$ based electrolytes were $10.3 \%, 10.0 \%$, and $10.3 \%$, respectively, using the organic Y123 dye under $1000 \mathrm{~W} \mathrm{~m}^{-2}$ AM1.5G illumination. The high photovoltaic performance of Cu-based redox mediators underlines the significant potential of the new redox mediators and points to a new research and development direction for DSCs.
\end{abstract}

\section{INTRODUCTION}

The drastic increase in worldwide energy demand combined with climate change has shifted interest in the past half-century toward renewable energy sources. Solar energy systems, including photovoltaics, show a rapid increase in development and industrialization and constitute to a very significant part in the field of renewable energy research. Dye-sensitized solar cells (DSC) achieve direct sunlight-to-electricity conversion by partially mimicking photosynthesis, rendering it a unique photovoltaic technology. ${ }^{1}$ This system offers a promising alternative to manufacture highly efficient solar cells in every color imaginable, including transparency made from environmentally friendly and very cost-efficient materials. ${ }^{2}$
In a DSC, dye molecules are anchored to a mesoscopic wide band gap semiconductor surface. Following light absorption, the photoexcited dye molecules inject electrons into the conduction band of the semiconductor (typically $\mathrm{TiO}_{2}$ ). The oxidized dye molecules are regenerated by a hole transport material, either a solid hole conductor or a liquid redox system, while the electrons injected into $\mathrm{TiO}_{2}$ provide electric work in the external circuit. The cycle is completed by the reduction of the oxidized redox species at a catalyst-loaded counter electrode surface. Since the discovery of DSCs, the iodide/tri-iodide

Received: October 13, 2016

Published: October 17, 2016 

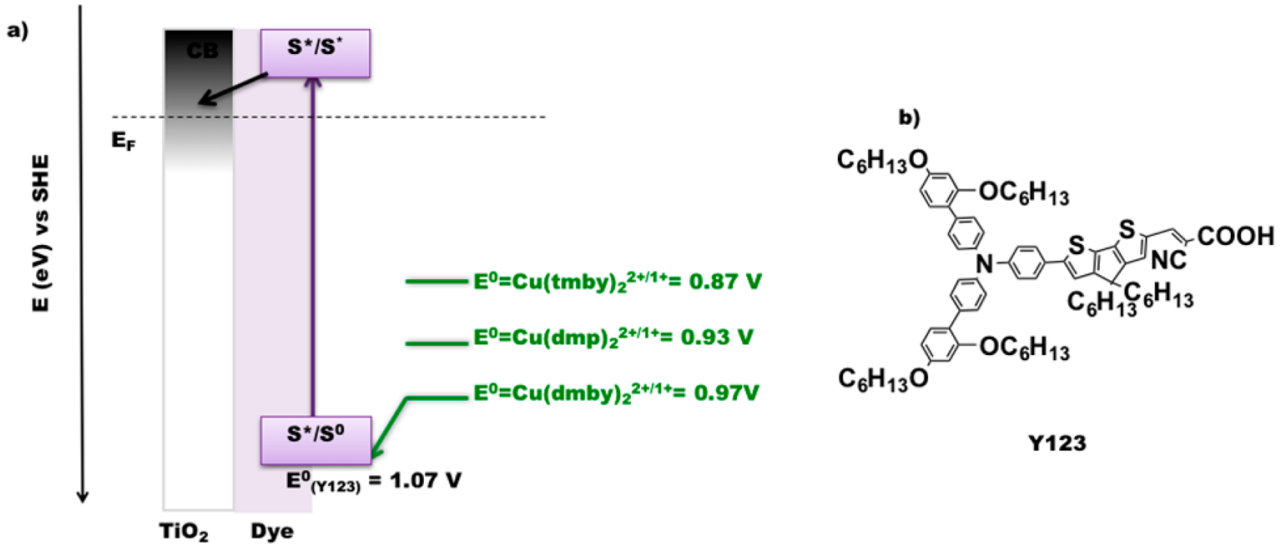

Y123

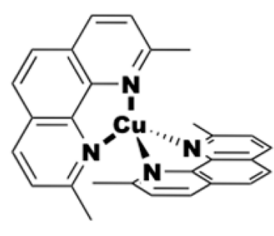

c) $\mathrm{Cu}(\mathrm{dmp})_{2}{ }^{2+/ 1+}$

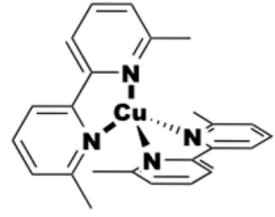

d) $\mathrm{Cu}(\mathrm{dmby})_{2}{ }^{2+/ 1+}$

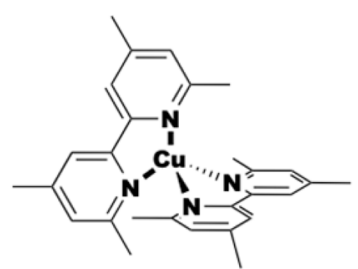

e) $\mathrm{Cu}(\mathrm{tmby})_{2}{ }^{2+/ 1+}$

Figure 1. (a) Schematic representation of energy levels in dye-sensitized solar cells. Molecular structures of the (b) $\left.\mathrm{Y} 123 \mathrm{dye},(\mathrm{c}) \mathrm{Cu}(\mathrm{dmp})_{2}\right]^{2+/ 1+}$, (d) $\left[\mathrm{Cu}(\mathrm{dmby})_{2}\right]^{2+/ 1+}$, and (e) $\left[\mathrm{Cu}(\text { tmby })_{2}\right]^{2+/ 1+}$ complexes.

redox couple has been conventionally used as the redox mediator, which has shown the highest efficiency values together with excellent stability data with different types of sensitizers in comparison to other redox mediators. ${ }^{2}$ The main advantage of this redox couple is the suppressed recombination of injected electrons with tri-iodide providing high photocurrents. However, being a two-electron redox couple, $\mathrm{I}^{-} / \mathrm{I}_{3}{ }^{-}$ electrolytes cause large internal potential losses for oxidized dye regeneration. In addition, there may be problems of corrosiveness and competitive visible light absorption., These disadvantages were overcome with one-electron-transfer cobalt complexes with more positive redox potentials, which resulted in an improved photovoltage and with overall higher efficiencies compared to those of the $\mathrm{I}^{-} / \mathrm{I}_{3}{ }^{-}$system. ${ }^{5-7}$ In these complexes, different ligand substitutions to the cobalt metal center enable the tuning of the redox potentials and electron transfer kinetics. So far, the highest efficiency value achieved is claimed to be above $14 \%$ for liquid-state DSCs with cobalt redox-mediator based electrolyte and dye-cosensitized working electrode. ${ }^{8}$ However, the large internal reorganization energy requirement between $\mathrm{d}^{7}$ (high spin) and $\mathrm{d}^{6}$ (low spin) states for cobalt complexes turns out to be a disadvantage by limiting the driving force available for dye regeneration. 9 The necessary driving force for dye regeneration was reported to be $230 \mathrm{mV}$ in order to achieve a 93\% regeneration yield with a triphenylamine-based organic dye ${ }^{10}$ which still gives a substantial potential loss. ${ }^{11,12}$ With a coordination number of six (octaheadral), the ligands linked to a cobalt metal center form bulky structures, leading to mass transport limitations in the mesoporous layer. ${ }^{13-15}$ Stability issues and toxicity concerns regarding cobalt complexes limit their potential for industrialization and mass production. ${ }^{16,17}$

As alternative redox mediators, copper complexes $(\mathrm{Cu}(\mathrm{I}) /$ $\mathrm{Cu}(\mathrm{II}))$ have been studied both as redox mediators ${ }^{18-21}$ and hole-transport materials (HTMs) ${ }^{22}$ in DSCs. First, Hattori et al. obtained a maximum photon to current efficiency (PCE) of
1.4\% with bis(2,9-dimethyl-1,10-phenantroline)copper(I)/(II) $\left[\mathrm{Cu}(\mathrm{dmp})_{2}\right]^{2+/+1}$, which has a distorted tetragonal shape providing a relatively low reorganization energy. ${ }^{19}$ The results were further improved by Bai et al., who reached $7 \% \mathrm{PCE}^{18}$ with the organic $\mathrm{C} 218$ dye, and recently, Freitag et al. attained 8.3\% PCE by having remarkably high open-circuit voltages $\left(V_{\text {oc }}\right)$ above $1.0 \mathrm{~V}$ with the organic $\mathrm{D}-\pi-\mathrm{A}$ LEG4 dye. ${ }^{23}$ Furthermore, it was reported that the $\left[\mathrm{Cu}(\mathrm{dmp})_{2}\right]^{2+/ 1+}$ complex with a redox potential of $0.93 \mathrm{~V}$ vs SHE is able to sufficiently regenerate the oxidized dye molecules with a small driving force $(0.2 \mathrm{eV})$, minimizing internal energy losses.

Herein, we report two new copper bipyridine complexes, 6,6'-dimethyl-2,2'-bipyridine ( $\left.\mathrm{Cu}^{\mathrm{II} / \mathrm{I})}(\mathrm{dmby})_{2} \mathrm{TFSI}_{2 / 1}\right)$ and $4,4^{\prime}, 6,6^{\prime}$-tetramethyl-2,2' -bipyridine ( $\mathrm{Cu}^{(\mathrm{II} / \mathrm{I})}\left(\right.$ tmby $\left._{2} \mathrm{TFSI}_{2 / 1}\right)$, which we examined in comparison to the reference [Cu$\left.(\mathrm{dmp})_{2}\right]^{2+/ 1+}$ complex in DSCs sensitized with the 3-\{6-\{4[bis $\left(2^{\prime}, 4^{\prime}\right.$-dihexyloxybiphenyl-4-yl)amino- $]$ phenyl $\}$-4,4-dihexylcyclopenta-[2,1-b:3,4- $\left.b^{\prime}\right]$ dithiphene-2-yl $\}$-2-cyanoacrylic (Y123) dye. ${ }^{10,24}$ We tuned the formal redox potentials of copper complexes relative to $\left[\mathrm{Cu}(\mathrm{dmp})_{2}\right]^{2+/ 1+}$ and investigated this change with respect to regeneration kinetics and device performance. By maintaining the coordination geometry around the copper metal center during the change of the $\mathrm{Cu}$ oxidation state from I to II, internal reorganization energies can be minimized, allowing the regeneration to proceed rapidly at low driving force. For $\mathrm{Cu}(\mathrm{I})$ bis-phenantroline complexes, the non-hydrogen groups at 2,9-positions of phenantroline ligand had already been reported to provide small changes in ligandcopper distances upon oxidation. ${ }^{25-27}$

Since $\mathrm{Cu}(\mathrm{dmp})_{2}$ is already proven a successful redox mediator for DSCs, the $\mathrm{Cu}(\mathrm{dmby})_{2}$ complex is similarly designed by keeping the methyl groups at 2,9-positions and replacing the phenantroline with bipyridine to tune the redox potential and other properties. The structure of the $\mathrm{Cu}(\mathrm{tmby})_{2}$ complex has two additional methyl groups at each ligand; the electron-donating effect of a methyl group (4,6-positions) shifts 
the redox potential by $100 \mathrm{mV}$ toward the negative. A schematic representation of the energy levels in DSC devices and molecular structures of the Y123 dye and the copper complexes are given in Figure 1. DSCs employing the new copper complexes as redox mediators reached photovoltages over $1.0 \mathrm{~V}$ in full sunlight allowing them to reach photoelectric conversion efficiency values higher than $10 \%$ for the complexes under study.

\section{EXPERIMENTAL SECTION}

All chemicals and solvents were purchased from Sigma-Aldrich, HetCat, and TCI Chemicals, if not otherwise stated, and were used without further purification.

Synthesis of Copper Complexes. The synthesis of copper complexes was performed as previously reported. ${ }^{28}$ For (Cu(dmp $)_{2}$ TFSI) (Figure S1), 1 equiv of $\mathrm{CuI}$ was mixed with 4 equiv of neocuproine hydrate in ethanol, under nitrogen atmosphere, at room temperature for $2 \mathrm{~h}$. The stirred solution was filtered and washed with water and diethyl ether. The resulting complex was collected as an intense red crystalline powder.

The $\mathrm{Cu}(\mathrm{dmp})_{2} \mathrm{TFSI}_{2}$ complex was produced by the oxidation of $\mathrm{Cu}(\mathrm{I})$ species with addition of $\mathrm{NOBF}_{4}$. Briefly, $\mathrm{Cu}(\mathrm{dmp})_{2}$ TFSI was dissolved in acetonitrile and 1 equiv of $\mathrm{NOBF}_{4}$, followed by 5 equiv of LiTFSI being added after $30 \mathrm{~min}$.

The solution was further stirred for $2 \mathrm{~h}$ at room temperature and nitrogen atmosphere. The solvent was removed by rotatory evaporation and the crude redissolved in minimum amount of dichloromethane (DCM). Cu(dmp $)_{2} \mathrm{TFSI}_{2}$ was collected by filtration after precipitation from diethyl ether and washed with diethyl ether. The product was a bright violet powder.

For complexation of $\mathrm{Cu}(\mathrm{dmby})_{2} \mathrm{TFSI}$ and $\mathrm{Cu}(\text { tmby })_{2}$ TFSI, 1 equiv of $\mathrm{CuI}$ was mixed with 3 equiv of dmby or tmby, respectively, in 20 $\mathrm{mL}$ of ethanol, under nitrogen atmosphere, at room temperature for 2 $\mathrm{h}$ (Figure S2). The resulting $\mathrm{Cu}(\mathrm{I})$ complexes were obtained as intense red crystalline powders. The $\mathrm{Cu}(\mathrm{I})$ products were filtered and redissolved by addition of $5 \mathrm{~mL}$ of deionized water followed by an addition of 5 equiv of LiTFSI. The solutions were further stirred for 2 $\mathrm{h}$ at room temperature under nitrogen atmosphere resulting in red precipitations. The complexes were collected by filtration and washed with water as bright red powders.

For $\mathrm{Cu}(\mathrm{dmby})_{2} \mathrm{TFSI}_{2}$ and $\mathrm{Cu}(\mathrm{tmby})_{2} \mathrm{TFSI}_{2} 1$ equiv of $\mathrm{CuCl}_{2}$ was mixed with 3 equiv of dmby or tmby, respectively, in $20 \mathrm{~mL}$ of ethanol, under nitrogen atmosphere, at room temperature for $2 \mathrm{~h}$. The resulting complexes were obtained as green powders. The product $\mathrm{Cu}$ (II) species were filtered and redissolved by addition of $5 \mathrm{~mL}$ of deionized water followed by an addition of 5 equiv of LiTFSI. The solution was further stirred for $2 \mathrm{~h}$ at room temperature and under nitrogen atmosphere. The complexes were collected by filtration as green powders and washed with water.

Electrochemical Characterization. Three-electrode cyclic voltammetry measurements were performed using a Autolab Pgstat-30 potentiostat with $\mathrm{Ag} / \mathrm{AgCl} /$ saturated $\mathrm{LiCl}$ (ethanol) as reference electrode and glassy carbon or platinum working electrodes under argon. Copper complexes were dissolved in acetonitrile, with LiTFSI $(0.1 \mathrm{M})$ as supporting electrolyte. Redox potentials were primarily referenced versus ferrocene, which was added in situ as voltammetric standard. The formal potential of $\mathrm{Fc} / \mathrm{Fc}^{+}$couple was between 0.468 and $0.471 \mathrm{~V}$ vs our $\mathrm{Ag} / \mathrm{AgCl}$ reference electrode.

Diffusion coefficient measurements were performed via rotating disk electrode voltammetry. A Bio Logic SP300 potentiostat with a quasi-reference platinum electrode and glassy carbon rotating disk electrode $(2.9 \mathrm{~mm}$, Radiometer Analytical-CVJ) was used in a solution of $0.1 \mathrm{M} \mathrm{LiTFSI}$ and $0.5 \mathrm{M}$ 4-tert-butylpyridine (TBP) in acetonitrile under argon atmosphere. The rotor speed was controlled by a speed control unit (Radiometer Analytical-CTV101). The cell temperature was kept constant at $25^{\circ} \mathrm{C}$ by a circulating water bath (HAAKE GH).

$\mathrm{UV} /$ vis absorption data were gathered by a Hewlett-Packard 8453 diode array spectrometer, and the extinction coefficients were calculated using the Lambert-Beer Law.
Device Fabrication. Preparation of the Working Electrodes. The photoanodes with a mesoporous $\mathrm{TiO}_{2}$ layer, counter electrodes, and electrolytes were prepared separately and then assembled in a solar cell device. For photoanodes, a glass pretreatment procedure was followed to remove the contaminations that can affect the preparation of the compact underlayer and thus the cell performance. FTO glasses (NSG-10, Nippon Sheet Glass) were first cleaned with a detergent solution (Deconex) in ultrasonic bath (45 min) and rinsed with water and ethanol. This initial step was followed by a $15 \mathrm{~min} \mathrm{UV} / \mathrm{O}_{3}$ treatment (Model no.256-220, Jelight Company, Inc.). Then the substrates were immersed into a $53 \mathrm{mM} \mathrm{TiCl}$ solution and kept at 70 ${ }^{\circ} \mathrm{C}$ in an oven for $30 \mathrm{~min}$ to allow the formation of thin and compact $\mathrm{TiO}_{2}$ underlayer. After $30 \mathrm{~min}$ the substrates were rinsed with water and ethanol. The $\mathrm{TiCl}_{4}$ treatment was followed by a $2 \mathrm{~h}$ annealing process at $250{ }^{\circ} \mathrm{C}$. Two layers of mesoporous $\mathrm{TiO}_{2}$ layers were prepared on top of the underlayer; the first layer was screen printed using a paste consisting of $30 \mathrm{~nm}$ in diameter sized $\mathrm{TiO}_{2}$ particles (Dyesol) and the second one with $400 \mathrm{~nm}$ sized particles (scattering layer). The substrates were sintered on a hot plate with a ramped temperature profile, keeping the temperature at $125,250,325,450$, and $500{ }^{\circ} \mathrm{C}$ for $5,5,5,15$, and $15 \mathrm{~min}$, respectively, with $5 \mathrm{~min}$ ramp duration between each temperature. The resulting $\mathrm{TiO}_{2}$ film thickness was $10 \mu \mathrm{m}(5 \mu \mathrm{m}+5 \mu \mathrm{m})$. To increase the surface area of the $\mathrm{TiO}_{2}$ particles, a $\mathrm{TiCl}_{4}$ post-treatment was performed, which was followed by another sintering process at $500{ }^{\circ} \mathrm{C}$ for $30 \mathrm{~min}$. Before dipping the $\mathrm{TiO}_{2}$ electrodes into dye solutions, they were annealed with a hot gun for $30 \mathrm{~min}$ at $500{ }^{\circ} \mathrm{C}$. After cooling down to $80^{\circ} \mathrm{C}$, they were put into the dye solution.

Dye Solutions. Y123 dye (Dyenamo AB, $0.1 \mathrm{mM}$ ) solutions were prepared in tert-butanol/acetonitrile $(1: 1 \mathrm{v} / \mathrm{v})$ mixture; $0.4 \mathrm{mM}$ chenodeoxycholic acid was used in the dye solutions as an additive to prevent aggregation. Working electrodes were dipped for $16 \mathrm{~h}$ in these solutions.

Preparation of the Counter Electrodes. FTO glass (TEC 6, Pilkington) as substrate for the counter electrodes was cleaned with Deconex (2\% wt in water), acetone, and ethanol with $30 \mathrm{~min}$ duration for each and coated with PEDOT via electrodeposition. ${ }^{29}$

The working electrodes and counter electrodes were assembled in a drybox with $25 \mu \mathrm{m}$ of Surlyn (Dupont), which provides the spacing between the two electrodes as well as sealing for the electrolyte. The electrolyte was introduced into the device through a predrilled hole in the counter electrode under vacuum. The electrolytes consisted of 0.2 $\mathrm{M} \mathrm{Cu}(\mathrm{I})$ and $0.04 \mathrm{M} \mathrm{Cu}(\mathrm{II})$ complexes with $0.1 \mathrm{M}$ LiTFSI and $0.6 \mathrm{M}$ TBP in acetonitrile.

Solar Cell Characterization. The device current-voltage $(I-V)$ characteristics were obtained by using a $450 \mathrm{~W}$ xenon light source (Oriel, U.S.A). A Keithley model 2400 digital source meter (Keithley, U.S.A) was used to apply an external potential bias to the devices and measure the resulting current.

Incident Photon to Current Conversion Efficiency (IPCE). IPCE data were acquired using a modulated light intensity with a frequency of $1 \mathrm{~Hz}$. The light, from a $300 \mathrm{~W}$ xenon light source (ILC Technology, USA), was focused through a monochromator (JobinYvon Ltd., UK) and directed to the device under test. A white light bias was used to have similar light intensity conditions as during normal operation.

Electron Lifetime Measurements. Electron lifetime measurements were performed using a white LED (Luxeon Star 1W) as light source. Voltage traces were recorded with a 16-bit resolution digital acquisition board (National Instruments) and lifetimes were determined by monitoring photovoltage transients at different light intensities upon applying a small square wave modulation to the base light intensity. The photovoltage responses were fitted using first-order kinetics to obtain time constants.

Photoinduced Absorption Spectroscopy (PIA). The photoinduced absorption spectra of the various cells were recorded over a wavelength range of 450-1000 $\mathrm{nm}$ following an (on/off) photomodulation using a $36 \mathrm{~Hz}$ square wave emanating from a blue laser $(406 \mathrm{~nm})$ filter through a notch (Balzers 405$)$. White probe light from a halogen lamp $(20 \mathrm{~W})$ was used as an illumination source. The light 
Table 1. Electrochemical and Absorption Data for $\mathrm{Cu}(\mathrm{I})$ and $\mathrm{Cu}(\mathrm{II})$ Species $^{a}$

$\begin{array}{lcccc} & \varepsilon\left(\mathrm{M}^{-1} \mathrm{~cm}^{-1}\right) & \lambda_{\max }(\mathrm{nm}) & D\left(\times 10^{-6} \mathrm{~cm}^{2} \mathrm{~s}^{-1}\right) & E^{0 \prime \prime}(\mathrm{V} \text { vs SHE }) \\ \mathrm{Cu}(\mathrm{I})(\mathrm{dmp})_{2} \text { TFSI } & 7300 & 457 & 12.6 & 0.93 \\ \left.\mathrm{Cu}(\mathrm{II})(\mathrm{dmp})_{2} \text { (TFSI }\right)_{2} & 850 & 360 & 14.4 & 0.97^{b} \\ \mathrm{Cu}(\mathrm{I})(\mathrm{dmby})_{2} \text { TFSI } & 6900 & 455 & 33.3 & \\ \mathrm{Cu}(\mathrm{II})(\text { dmby })_{2} \text { TFSI/Cl } & 1300 & 360 & 11.2 & 0.87^{b} \\ \mathrm{Cu}(\mathrm{I})(\mathrm{tmby})_{2} \text { TFSI } & 5300 & 451 & 22.0 & \\ \mathrm{Cu}(\mathrm{II})(\text { tmby })_{2} \text { TFSI/Cl } & 1400 & 360 & \end{array}$

${ }^{a} \varepsilon$ : extinction coefficient, $\lambda_{\max }=$ absorption peak wavelength, $D$ : diffusion coefficient, $E^{0 \prime \prime}$ : formal redox potential) ${ }^{b}$ These formal potentials are determined from the voltammogram of $\mathrm{Cu}(\mathrm{I})$ species only.
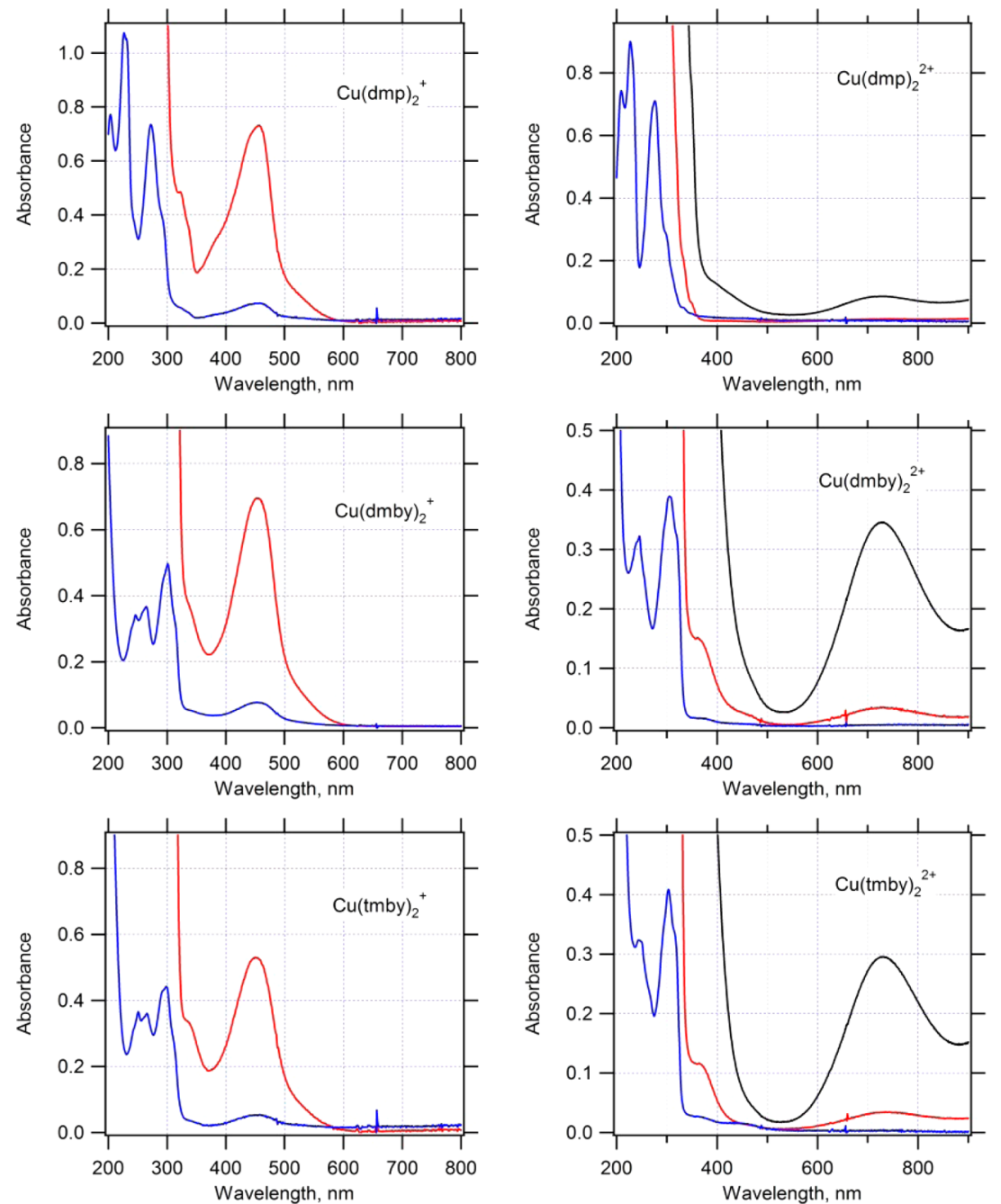

Figure 2. UV-vis spectra of $\mathrm{CuL}_{2} \mathrm{TFS} I_{1 / 2}(\mathrm{~L}=$ ligand) in acetonitrile solution; concentration: $50 \mu \mathrm{M}$ (blue curves), $0.5 \mathrm{mM}$ (red curves), and 5 $\mathrm{mM}$ (black curves). Optical cell thickness $2 \mathrm{~mm}$.

was focused into a monochromator (Horiba, Gemini) and detected using a $\mathrm{Si}$ photodiode with a gain of 10 , connected to a lock-in amplifier (Stanford Research Systems model SR830).

Transient Absorption Spectra (TAS). The photoinduced kinetics were measured with an Ekspla NT-342 Q-switched Nd:YAG laser using $532 \mathrm{~nm}$ as excitation wavelength. The pulse width was $4-5 \mathrm{~ns}$ (FWHM), and the repetition rate was $20 \mathrm{~Hz}$. The probe light source was a halogen lamp, and the probe wavelength at $715 \mathrm{~nm}$ was chosen using a monochromator. The film was positioned at approximately $45^{\circ}$ angle with respect to the incoming laser pulse for front illumination. The signal was detected using the photomultiplier tube R9110 from Hamamatsu and recorded using the oscilloscope DPO 7254 from Tektronix. The radiant output of the laser was attenuated using gray optical density filters to $46 \mu \mathrm{J} / \mathrm{cm}^{2}$ for the measurements of the samples containing redox mediators and $1.27 \mu \mathrm{J} / \mathrm{cm}^{2}$ for the electrolytically inert samples. A low light intensity value was deliberately chosen in order to ensure that the data could be fitted to single exponential functions from which the lifetimes could be obtained. An acquisition was averaged over 3000 laser shots.

\section{RESULTS AND DISCUSSION}

Electrochemical and Spectroscopic Data. The formal redox potentials, extinction coefficients and diffusion coefficients of the investigated complexes, are tabulated in Table 1. The formal redox potentials of the $\left[\mathrm{Cu}(\mathrm{dmby})_{2}\right]^{2+/ 1+}$ and $\left[\mathrm{Cu}(\mathrm{tmby})_{2}\right]^{2+/ 1+}$ complexes are determined by cyclic voltam- 


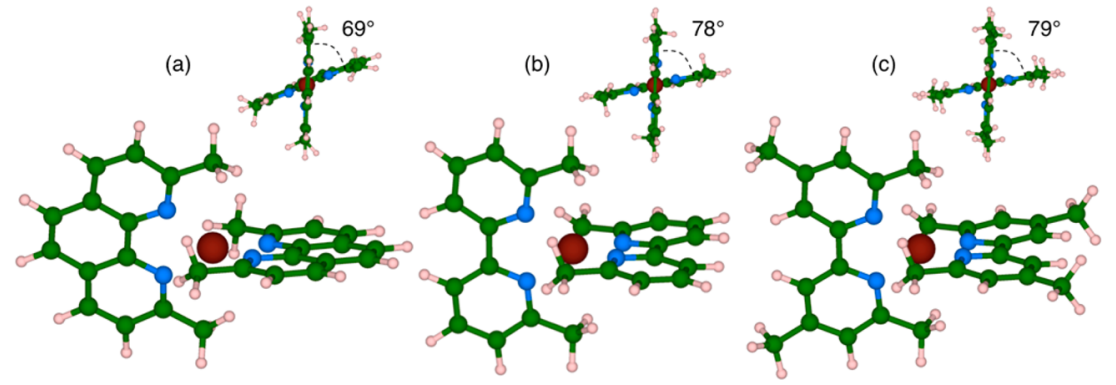

Figure 3. $\mathrm{Cu}(\mathrm{II}) \mathrm{L}_{2}$ minimum-energy structures. $\mathrm{L}=\mathrm{dmp}(\mathrm{a})$, dmby (b), and tmby (c).

metry using a three-electrode setup with a glassy carbon working electrode.

From the obtained reversible voltammograms (with equal anodic and cathodic peak currents after repeated cycles) of $\mathrm{Cu}(1)$ species, the formal (conditional) redox potentials for $\left[\mathrm{Cu}(\mathrm{dmby})_{2}\right]^{2+/ 1+}$ and $\left[\mathrm{Cu}(\mathrm{tmby})_{2}\right]^{2+/ 1+}$ are determined. If we omit the difference in activity coefficients, then the potentials can be approximated to the standard electrochemical potential, with 0.97 and $0.87 \mathrm{~V}$ vs the standard hydrogen electrode (SHE) for $\left[\mathrm{Cu}(\mathrm{dmby})_{2}\right]^{2+/ 1+}$ and $\left[\mathrm{Cu}(\text { tmby })_{2}\right]^{2+/ 1+}$, respectively. The redox potentials were referenced to SHE by addition of $0.624 \mathrm{~V}$ with respect to the formal potential of the reference ferrocene/ ferrocenium redox couple (Figure S3).

The different substitutions of the bipyridine ligands have an explicit influence on the redox potential of the complexes. The dimethyl substitution of the bipyridine ligands provides a higher redox potential for $\left[\mathrm{Cu}(\mathrm{dmby})_{2}\right]^{2+/ 1}$, whereas the additional two methyl groups giving the electron donation function lower the redox potential for $\left[\mathrm{Cu}(\mathrm{tmby})_{2}\right]^{2+/ 1+}$. The redox potential of $\left[\mathrm{Cu}(\mathrm{dmp})_{2}\right]^{2+/ 1+}$ has been reported to be $0.94 \mathrm{~V}$ vs $\mathrm{SHE}^{28}$

In the case of $\left[\mathrm{Cu}(\mathrm{tmby})_{2}\right]^{2+}$ and $\left[\mathrm{Cu}(\mathrm{dmby})_{2}\right]^{2+}$ species, we observe more complex voltammograms with negative shifts against the redox wave of $\left[\mathrm{Cu}(\mathrm{tmby})_{2}\right]^{1+}$ and $\left[\mathrm{Cu}(\mathrm{dmby})_{2}\right]^{1+}$. Solely in the case of phenanthroline complex, the formal redox potentials of $\mathrm{Cu}(\mathrm{II})$ and $\mathrm{Cu}(\mathrm{I})$ species were matching. To address this issue furthermore, an additional study was carried out, in which the $\mathrm{Cu}(\mathrm{dmby})^{2+}$ and $\mathrm{Cu}(\text { tmby })^{2+}$ were backreduced chemically, either by ferrocene or by ascorbic acid. In all cases, simple voltammograms of $\mathrm{Cu}(\mathrm{I})$ species were obtained, which points out the purity of the $\mathrm{Cu}$ (II) complexes (Figure S4). The reduction of $\mathrm{Cu}(\mathrm{tmby})^{2+}$ by ferrocene caused precipitation in the electrolyte solution so that the voltammogram cannot be considered quantitative, but an upshift of the redox waves of the reduction product is obvious (Figure S4). A more elegant way of reducing $\mathrm{Cu}(\text { tmby })^{2+}$ to $\mathrm{Cu}(\mathrm{tmby})^{1+}$ is the use of ascorbic acid (Figure S4). The electrochemical data shows that the reaction of $\mathrm{CuCl}_{2}$ with the corresponding ligand provides more complex products than originally assumed. It can be assumed that the TFSI anion is coordinating to $\mathrm{Cu}$ (II) center, leading to the two species deferring in redox potentials. In contrast, the chemical oxidation of $\mathrm{Cu}(\mathrm{dmp})^{+}$by $\mathrm{NOBF}_{4}$ provided a single species as shown in Figure S3a.

In a more recent work by Hupp and co-workers, $\mathrm{TiO}_{2}$ conduction band edge shifts were attributed to the result of the coordination changes of the copper species due to excess TBP. $^{30}$ In addition to standard electrochemical potential determinations, cyclic voltammetry experiments were also performed in excess TBP conditions (2.5 times higher molar excess of TBP referenced to $\mathrm{Cu}(\mathrm{I})$, similar to the electrolyte solution). In the case of excess TBP, significant negative shifts (about $20 \mathrm{mV}$ ) in the redox potentials were observed for the three investigated complexes, which also enhance the dye regeneration efficiencies by the increased driving forces (Figure S3).

The absorption spectra of $\mathrm{Cu}(\mathrm{I})(\text { tmby })_{2}, \mathrm{Cu}(\mathrm{I})(\mathrm{dmby})_{2}$, and $\mathrm{Cu}(\mathrm{I})(\mathrm{dmp})_{2}$ show absorption maxima at $\lambda_{\max }=450-460$ $\mathrm{nm}$ in acetonitrile, attributed to the metal-to-ligand charge transfer (MLCT) transitions (Figure 2 and S5). For $\mathrm{Cu}(\mathrm{II})$ species, the absorption peaks are observed in the UV region assigned to $\pi \rightarrow \pi^{*}$ transitions (Figure 2).

To compare the diffusion coefficients of the copper complexes, rotating disk electrode measurements were carried out. The results were analyzed with the use of the KouteckyLevich equation. It is observed that copper complexes have higher diffusion coefficients in comparison to that of cobalt trisbipyridine complex. Each copper atom (with coordination number 4) is chelated with 2 ligands, whereas cobalt complexes (coordination number of 6) require 3 ligands. The copper complexes have smaller molecular size and therefore higher diffusion coefficients and thus can easily diffuse in the mesoporous structure. The diffusion coefficients for $\mathrm{Co}$ (III) $(\text { bpy })_{3}(\mathrm{TFSI})_{3}$ and $\mathrm{Co}(\mathrm{II})(\mathrm{bpy})_{3}(\mathrm{TFSI})_{2}$ were determined to be $7.2 \times 10^{-6}$ and $6.1 \times 10^{-6} \mathrm{~cm}^{2} \mathrm{~s}^{-1}$, respectively, under the same experimental conditions.

Density Functional Theory Calculations (DFT). In order to estimate the reaction free energies and internal reorganization energies for the three copper complexes, we performed DFT calculations with the Gaussian 09 suite of programs ${ }^{31}$ at the PBE0 level of theory ${ }^{32}$ with SDD ECP as basis set for $\mathrm{Cu}$ and TZVP basis set for other atoms. Structural optimizations, molecular frequencies, and thermochemistry data were obtained in solution with the polarizable continuum model (PCM) for acetonitrile. ${ }^{33,34}$ Vertical excitation energies have been computed with time-dependent DFT (TD-DFT) at the same level of theory. ${ }^{35}$

For the three copper(I) complexes, HOMO and LUMO are both doubly degenerate. For $\left[\mathrm{Cu}(\mathrm{dmp})_{2}\right]^{1+}$, the computed first electronic transition $\left(\Delta E_{\text {exc }}\right)$ at $466 \mathrm{~nm}$ (Table S1) corresponds to HOMO-LUMO transition and has a clear metal-to-ligand charge transfer character, Figure S6. The molecular orbitals for $\left[\mathrm{Cu}(\text { tmby })_{2}\right]^{1+}$ and $\left[\mathrm{Cu}(\mathrm{dmby})_{2}\right]^{1+}$ present similar qualitative features.

According to the computations, copper(I) ligands stay in a perpendicular configuration (Figure S7), providing a tetrahedral coordination sphere for copper. Upon oxidation, the perpendicular alignment decays to a distorted tetragonal structure (Figure 3 and Table S2): The most favored squareplanar $\mathrm{Cu}(\mathrm{II})$ coordination is prevented by the steric hindrance effects of the methyl groups in 2,9-positions of the ligands. The 
free energy difference $\left(\Delta G_{\text {ox }}\right)$ for oxidation of copper species and the internal reorganization energies $\left(\lambda_{\text {in }}\right)$ have been calculated for such configurations, and the results are listed in Table 2 . These free energy values are qualitatively consistent

Table 2. Free Energy Differences for the $\mathrm{Cu}(\mathrm{I}) \rightarrow \mathrm{Cu}(\mathrm{II})$ Process $\left(\Delta G_{\mathrm{ox}}\right)$ and Corresponding Inner-Sphere Reorganization Energy $\left(\lambda_{\text {in }}\right)$

\begin{tabular}{lcc} 
& $\Delta G_{\text {ox }}(\mathrm{eV})$ & $\lambda_{\text {in }}(\mathrm{eV})$ \\
{$\left[\mathrm{Cu}(\mathrm{dmp})_{2}\right]^{1+/ 2+}$} & 4.68 & 0.281 \\
{$\left[\mathrm{Cu}(\mathrm{dmby})_{2}\right]^{1+/ 2+}$} & 4.64 & 0.301 \\
{$\left[\mathrm{Cu}(\mathrm{tmby})_{2}\right]^{1+2+}$} & 4.47 & 0.294 \\
{$\left[\mathrm{Co}(\mathrm{bpy})_{2}\right]^{2+/ 3+}(\text { low-spin })^{36}$} & 5.00 & 0.613 \\
\hline
\end{tabular}

with the observed trend in experimental oxidation potentials. For the three copper complexes, the predicted inner-sphere reorganization energies are very low, about $0.3 \mathrm{eV}$, in comparison with those of cobalt species: For $\mathrm{Co}(\mathrm{bpy})_{3}$ and related complexes, the $\lambda_{\text {in }}$ values, computed with the same approach, lie in the range of $0.52-0.63 \mathrm{eV}$ (considering $\mathrm{Co}$ (II) low spin) and 1.39-1.78 eV (for Co(II) high spin). ${ }^{36}$ We have only addressed the internal (inner-sphere) reorganization energy because recent works from other groups ${ }^{36,37}$ have proven that this parameter $\left(\lambda_{\text {in }}\right)$ is the key feature limiting the overall dye regeneration process by Co-based redox mediators.

It is found that these low reorganization energy values for the copper complexes originate from very small changes in ligandcopper distances upon oxidation, which are only $\sim 2 \%$ for $\mathrm{Cu}$ ligand (against $\sim 10 \%$ for Co-ligand complexes). ${ }^{36}$ Moreover, the $\mathrm{Cu}(\mathrm{I})$ ion in its spherically symmetric $3 \mathrm{~d}^{10}$ electronic configuration is less sensitive than $\mathrm{Co}$ (II) to structural distortions in the ligand coordination sphere. For copper complexes with the smaller reorganization energies, the driving force for dye regeneration can be kept small to obtain improved photovoltages.

Photovoltaic Performance of Dye-Sensitized Solar Cells with Copper Complexes. The photocurrent-voltage data of solar cells containing the three different copper redox mediators and Y123-sensitized $\mathrm{TiO}_{2}$ films dye are given in Figure 4.

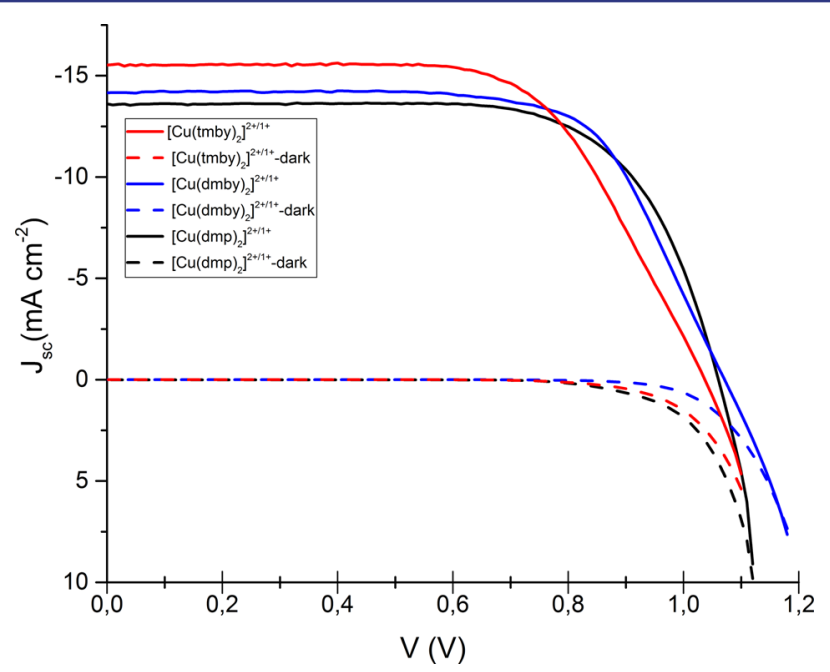

Figure 4. Photocurrent density vs voltage $(J-V)$ curves measured under standard AM 1.5G illumination and in the dark for solar cells sensitized with Y123 dye and employing copper complexes.
The photocurrent densities, open-circuit voltages, fill factors, and power conversion efficiencies of the DSC devices employing the $\left[\mathrm{Cu}(\mathrm{tmby})_{2}\right]^{2+/ 1+},\left[\mathrm{Cu}(\mathrm{dmby})_{2}\right]^{2+/ 1+}$, and $[\mathrm{Cu}-$ $\left.(\mathrm{dmp})_{2}\right]^{2+/ 1+}$ complexes are summarized in Table 3 (see also

Table 3. I-V Characteristics for the $\left[\mathrm{Cu}(\mathrm{dmp})_{2}\right]^{2+/ 1+}$, $\left[\mathrm{Cu}(\mathrm{dmby})_{2}\right]^{2+/ 1+}$, and $\left[\mathrm{Cu}(\mathrm{tmby})_{2}\right]^{2+/ 1+}$ Complexes

\begin{tabular}{ccccc}
\multicolumn{1}{c}{ redox couple } & $V_{\text {oc }}(\mathrm{V})$ & $J_{\text {sc }}\left(\mathrm{mA} \mathrm{cm}^{-2}\right)$ & FF & PCE (\%) \\
{$\left[\mathrm{Cu}(\mathrm{tmby})_{2}\right]^{2+/ 1+}$} & 1.04 & 15.53 & 0.640 & 10.3 \\
{$\left[\mathrm{Cu}(\mathrm{dmby})_{2}\right]^{2+/ 1+}$} & 1.07 & 14.15 & 0.687 & 10.0 \\
{$\left[\mathrm{Cu}(\mathrm{dmp})_{2}\right]^{2+/ 1+}$} & 1.06 & 13.61 & 0.692 & 10.3 \\
\hline
\end{tabular}

Figures S8-10) The power conversion efficiency is calculated using

$$
\eta=J_{\mathrm{sc}} \times V_{\mathrm{oc}} \times \frac{\mathrm{FF}}{I_{0}}
$$

where $J_{\mathrm{sc}}$ is the current density, $V_{\mathrm{oc}}$ is the open circuit voltage, FF is fill factor and $I_{0}$ is the incident light intensity. For all complexes, PCEs above $10 \%$ at AM 1.5 G illumination were reached. These are to our knowledge the highest PCEs reported for DSCs based on $\mathrm{Cu}$ complexes as redox mediators. The three redox couples show remarkably high open-circuit voltage values of more than $1.0 \mathrm{~V}$ at full sunlight illumination. Evidently, a regular trend between the formal redox potentials (Table 1) and the $V_{\mathrm{oc}}$ values was observed. Though the trend between $V_{\mathrm{oc}}$ and $E^{0 \prime}$ is proportional, there are other effects to be taken into account in the discussion of the open circuit voltages of the DSCs. This will be further discussed below in relation to recombination and conduction band edge shifts with electron lifetimes and charge extraction measurements, respectively. The short-circuit current density is observed to be highest for the $\left[\mathrm{Cu}(\mathrm{tmby})_{2}\right]^{2+/ 1+}$ electrolyte as a result of the highest driving force available for dye regeneration. Having the highest extinction coefficients for $\mathrm{Cu}(\mathrm{I}),\left[\mathrm{Cu}(\mathrm{dmp})_{2}\right]^{1+/ 2+}$ complex shows the lowest short-circuit current density due to the competitive light absorbance.

The IPCE spectra for the DSC devices employing the three different redox couples are given in Figure 5. For $[\mathrm{Cu}-$ $\left.(\mathrm{tmby})_{2}\right]^{2+/ 1+}$ based electrolyte, the maximum IPCE is found to be $92 \%$ at $520 \mathrm{~nm}$. For $\left[\mathrm{Cu}(\mathrm{dmp})_{2}\right]^{2+/ 1+}$ and $[\mathrm{Cu}-$

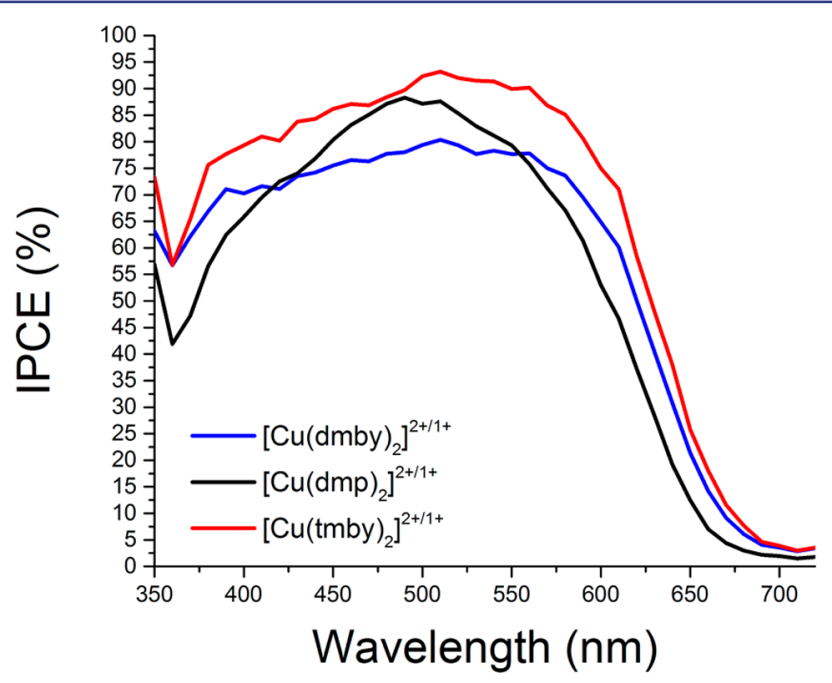

Figure 5. IPCE spectra of DSC devices sensitized with Y123 dye. 
$\left.(\mathrm{dmby})_{2}\right]^{2+/ 1+}$, the maxima are 85 and $75 \%$, respectively, around $500 \mathrm{~nm}$. The drop of IPCE at 360 and $450 \mathrm{~nm}$ is ascribed to the absorption of $\mathrm{Cu}(\mathrm{I})$ and $\mathrm{Cu}$ (II) species in these regions. For further analysis, IPCE can be expressed as

$$
\operatorname{IPCE}=\operatorname{LHE} \Phi_{\text {inj }} \eta_{\text {coll }}
$$

where LHE is light-harvesting efficiency, $\Phi_{\text {inj }}$ is the quantum yield of electron injection, and $\eta_{\text {coll }}$ is the photogenerated charge collection efficiency. By assuming similar LHE and $\Phi_{\text {inj }}$ values (same dye and same working electrode parameters), the $\eta_{\text {coll }}$ values can be compared for the copper complexes under study. The $\left[\mathrm{Cu}(\mathrm{tmby})_{2}\right]^{2+/ 1+}$ electrolyte showed the best charge collection efficiencies due to the increased driving force for dye regeneration and presumably reduced recombination as indicated from electron lifetime measurements (electron lifetimes are measured under open circuit conditions). The broader IPCE spectrum for the $\left[\mathrm{Cu}(\mathrm{tmby})_{2}\right]^{2+/ 1+}$ complex is attributed both to the electron collection yield due to longer electron lifetimes in the $\mathrm{TiO}_{2}$ and lower extinction coefficient of this complex. The slightly blue-shifted IPCE of $[\mathrm{Cu}-$ $\left.(\mathrm{dmp})_{2}\right]^{2+/ 1+}$ shows higher competitive light absorption for this complex.

Electron Lifetime Measurements. To understand the recombination reaction between the oxidized form of the redox species and injected electrons in $\mathrm{TiO}_{2}$, electron lifetime and charge extraction measurements were carried out. Semilogarithmic plots of the measured electron lifetimes with respect to the quasi-Fermi level of the electrons in the $\mathrm{TiO}_{2}$ electrode of the complete devices are given in Figure 6. At the

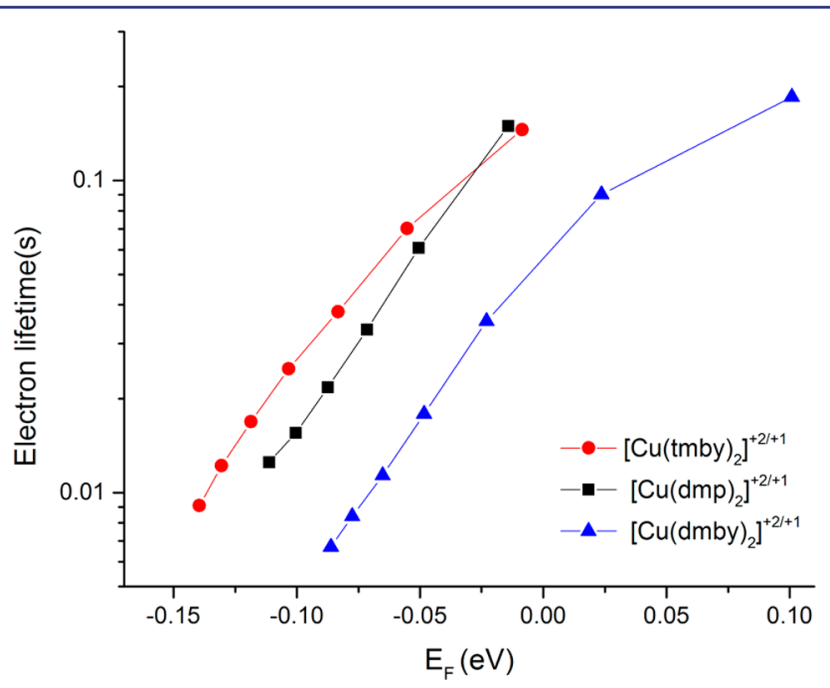

Figure 6. Electron lifetimes for the three copper complexes.

same Fermi level ( $-0.05 \mathrm{~V}$ vs SHE) the electron lifetimes were measured as $0.036,0.021$, and $0.006 \mathrm{~s}$ for the $\left[\mathrm{Cu}(\mathrm{tmby})_{2}\right]^{2+/ 1+}$, $\left[\mathrm{Cu}(\mathrm{dmp})_{2}\right]^{2+/ 1+}$, and $\left[\mathrm{Cu}(\mathrm{dmby})_{2}\right]^{2+/ 1+}$, respectively. The electron lifetime values indicate that the recombination reaction is driving-force-dependent, corresponding to the Marcus normal region. The effect of steric properties of the ligands on the copper complexes is calculated to be similar to that for the recombination reaction due to similar reorganization energy values (Table 2) and therefore neglected. Electron lifetimes followed a coherent trend with respect to the driving force for recombination reaction. Since the driving force for recombination is the lowest in the case of $\left[\mathrm{Cu}(\mathrm{tmby})_{2}\right]^{2+/ 1+}$ complex, the electron lifetime showed higher values in comparison to the those of other complexes. By having the most positive formal redox potential, the $\left[\mathrm{Cu}(\mathrm{dmby})_{2}\right]^{2+/ 1+}$ complex resulted in lower electron lifetimes. The changes in the slopes of the electron lifetime data (see Figure 6) of the copper complexes is attributed to the recombination of electrons with FTO substrates at low currents. Preventing recombination at low currents can be achieved by better blocking layer processing and sensitizers with blocking properties. ${ }^{38}$

The fact that the $V_{\mathrm{OC}}$ values from the different $\mathrm{Cu}$-complexes are similar, above $1.0 \mathrm{~V}$, although the redox potentials differ by about $0.1 \mathrm{~V}$, can be explained together by the differences in electron lifetimes and conduction band shifts. The $V_{\mathrm{OC}}$ value will be a compromise between driving force and recombination. For a larger driving force there will be a bigger internal potential drop between the redox potential of the electrolyte and the oxidation potential of the dye, leading to relatively lower $V_{\mathrm{OC}}$. At the same time, dye regeneration will be faster and more efficient (see below). Faster dye regeneration will intercept the recombination reaction between electrons in the $\mathrm{TiO}_{2}$ and oxidized dye and lead to a longer electron lifetime. This is an indication of higher electron concentration in the $\mathrm{TiO}_{2}$, which means a higher quasi-Fermi level of the electrons and a relatively higher $V_{\mathrm{OC}}$. Even if the $\left[\mathrm{Cu}(\mathrm{tmby})_{2}\right]^{2+/ 1+}$ complex has a lower redox potential, $0.1 \mathrm{~V}$ lower compared to $\left[\mathrm{Cu}(\mathrm{dmby})_{2}\right]^{2+/ 1+}$, the $V_{\mathrm{OC}}$ values are similar due to longer electron lifetimes for $\left[\mathrm{Cu}(\mathrm{tmby})_{2}\right]^{2+/ 1+}$. The contribution of conduction band positions on $V_{\mathrm{OC}}$ can be observed via the charge extraction data. For the studied complexes, the charge extraction values normalized to Fermi level of the $\mathrm{TiO}_{2}$ are given in Figure S11. At a certain value of extracted charge, the conduction band positions appeared to be most negative for $\left[\mathrm{Cu}(\mathrm{dmp})_{2}\right]^{2+/ 1+}$ which is followed by $\left[\mathrm{Cu}(\mathrm{tmby})_{2}\right]^{2+/ 1+}$ and $\left[\mathrm{Cu}(\mathrm{dmby})_{2}\right]^{2+/ 1+}$. By having the most negative conduction band position and longer electron lifetimes, $\left[\mathrm{Cu}(\mathrm{dmp})_{2}\right]^{2+/ 1+}$ could reach to $V_{\mathrm{OC}}$ values similar to the values of $[\mathrm{Cu}-$ $\left.(\mathrm{dmby})_{2}\right]^{2+/ 1+}$ although the redox potential is lower. The differences in conduction band edges are attributed to the coordination changes due to TFSI and TBP especially for $\left[\mathrm{Cu}(\mathrm{tmby})_{2}\right]^{2+}$ and $\left[\mathrm{Cu}(\mathrm{dmby})_{2}\right]^{2+}$, in which the effect of coordination differences are clearly observable via cyclic voltammograms (Figure 3). The mechanism related to the coordination sphere changes will be studied later.

The light intensity dependence of the short circuit current density and photovoltage are given in Figure 7. The $J_{\mathrm{SC}}$ values showed a linear dependence for $\left[\mathrm{Cu}(\mathrm{tmby})_{2}\right]^{2+/ 1+}$ complex. For the $\left[\mathrm{Cu}(\mathrm{dmp})_{2}\right]^{2+/ 1+}$ and $\left[\mathrm{Cu}(\mathrm{dmby})_{2}\right]^{2+/ 1+}$ complexes, the photocurrent deviates from linearity with increasing light intensities. This effect can be explained with mass transport limitations of the copper complexes. Under higher light intensities, diffusion problems gives rise to a higher internal series resistance. This will result in a nonlinear behavior of the photocurrent with light intensity as well as limitations of the fill factor in the DSC device. The high photovoltage stays nearly independent of illumination intensity above 0.2 sun, being higher than $1.0 \mathrm{~V}$ at 0.2 sun for the $\left[\mathrm{Cu}(\mathrm{tmby})_{2}\right]^{2+/ 1+}$ and $\left[\mathrm{Cu}(\mathrm{dmp})_{2}\right]^{2+/ 1+}$ complexes. This feature gives copper complexes an intriguing potential for use in devices for diffuse light and indoor applications.

Dye Regeneration. The regeneration kinetics of the Y123 chromophor by the three copper complexes were investigated with photoinduced absorption spectroscopy (PIA). The PIA spectra for the inert electrolyte solution together with the $\left[\mathrm{Cu}(\mathrm{dmp})_{2}\right]^{2+/ 1+},\left[\mathrm{Cu}(\mathrm{dmby})_{2}\right]^{2+/ 1+}$, and $\left[\mathrm{Cu}(\mathrm{tmby})_{2}\right]^{2+/ 1+}$ 

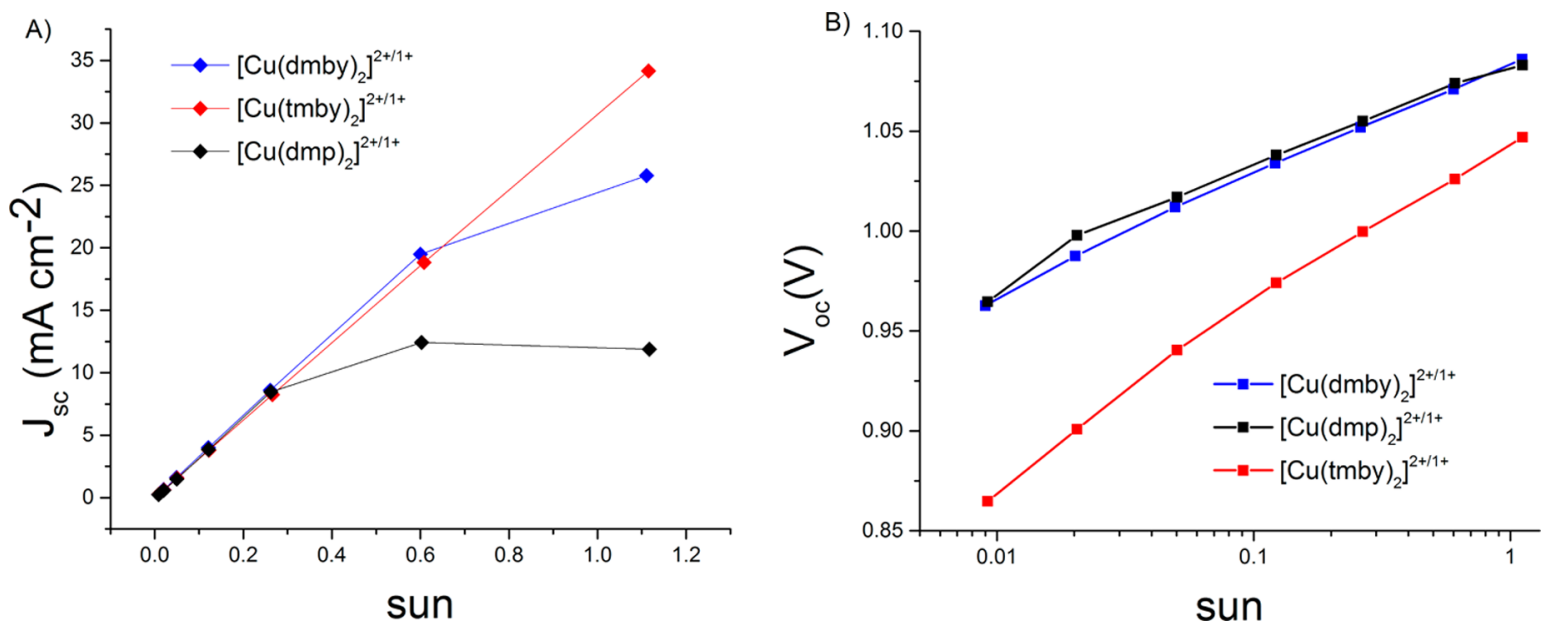

Figure 7. Light intensity dependence of (A) short-circuit current and (B) photovoltage for DSC devices based on the three different copper electrolytes.

electrolytes are given in Figure 8. Without the redox couple in the electrolyte, a bleach was observed at $540 \mathrm{~nm}$ due to the

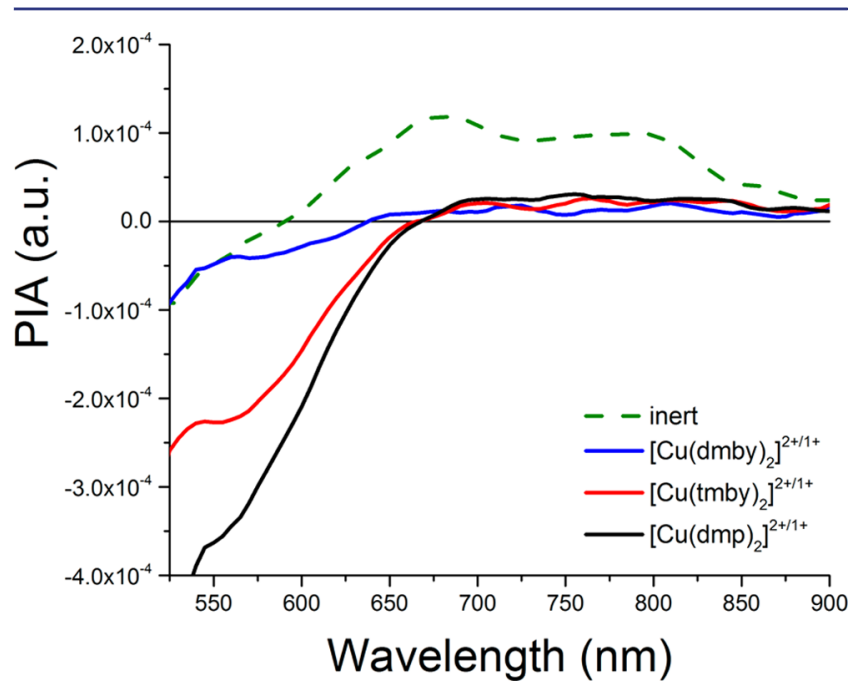

Figure 8. PIA spectra of $\mathrm{Y} 123$-sensitized $\mathrm{TiO}_{2}$ with an inert electrolyte and with electrolytes prepared with the three different copper complexes.

ground-state bleach of the dye upon oxidation and Stark shift, i.e., absorption change of the dye as a result of changes in the electrical field across the dye molecules by the photoinjected electrons. ${ }^{39,40}$ We also observe absorption peaks of the oxidized dye appearing at 680 and $800 \mathrm{~nm}$ in the absence of the copper complexes. In the spectra of copper complexes, the bleach persisted around $520 \mathrm{~nm}$ as a result of the Stark effect, whereas the absorption peaks of the oxidized dye disappear due to efficient regeneration of the oxidized dye molecules with the redox species. The positive signal remaining in the PIA spectra higher than $650 \mathrm{~nm}$ is attributed to the absorption of electrons that are accumulated in $\mathrm{TiO}_{2}$. From the results of the PIA measurements it can be concluded that the copper complexes can effectively regenerate the oxidized dye species.

Transient Absorption Spectroscopy. Dye regeneration kinetics with the copper complexes were further investigated with nanosecond transient absorption spectroscopy (TAS) measurements, Figure 9. With an inert electrolyte $(0.1 \mathrm{M}$

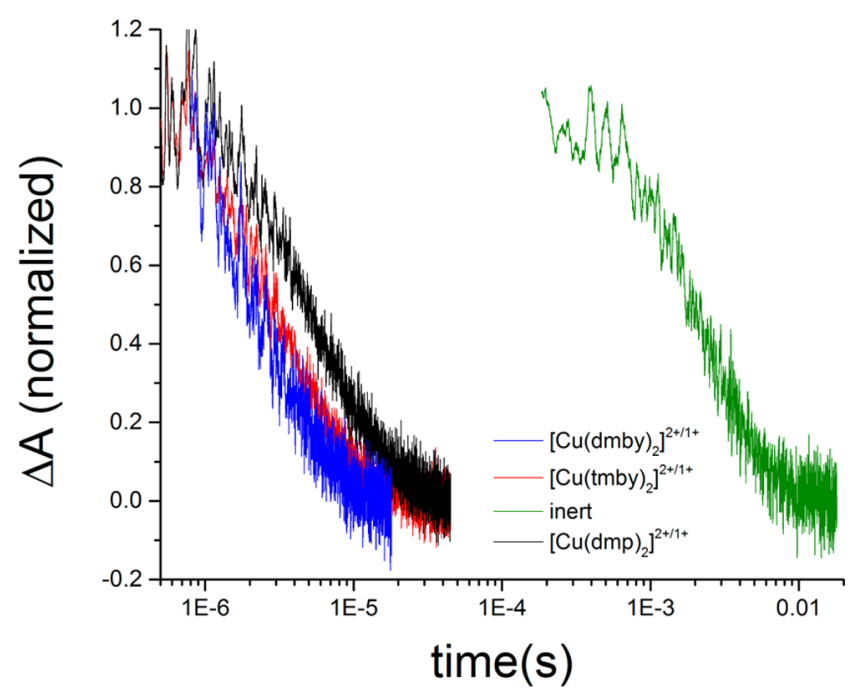

Figure 9. Transient absorption spectroscopy measurements of Y123sensitized $\mathrm{TiO}_{2}$ films with inert, $\left[\mathrm{Cu}(\mathrm{dmby})_{2}\right]^{2+/ 1+},\left[\mathrm{Cu}(\mathrm{tmby})_{2}\right]^{2+/ 1+}$, and $\left[\mathrm{Cu}(\mathrm{dmp})_{2}\right]^{2+/ 1+}$ electrolytes.

LiTFSI and 0.6 M TBP in acetonitrile), the recombination of injected electrons in the $\mathrm{TiO}_{2}$ and oxidized dye molecules showed an absorbance decay signal with a $10 \mathrm{~ms}$ half-time $\left(\tau_{1 / 2}\right)$. This is significantly slower than previously reported value for this dye which can be explained by the lower laser light intensity used in this work $\left(1.27 \mu \mathrm{J} / \mathrm{cm}^{2}\right)$ with respect to that in the reference study $\left(20 \mu \mathrm{J} / \mathrm{cm}^{2}\right) .{ }^{10}$ In the presence of copper complexes, the absorbance signal shows an accelerated decay by the faster regeneration of oxidized dye molecules with $\mathrm{Cu}^{1+}$ species. The regeneration half-times of $\left[\mathrm{Cu}(\mathrm{tmby})_{2}\right]^{2+/ 1+}$, $\left[\mathrm{Cu}(\mathrm{dmp})_{2}\right]^{2+/ 1+}$, and $\left[\mathrm{Cu}(\mathrm{dmby})_{2}\right]^{2+/ 1+}$ are $1.8,2.8$, and $4.8 \mu \mathrm{s}$, respectively, under the same conditions, showing a direct relation to the driving forces for dye regeneration. The regeneration efficiencies $\left(\Phi_{\text {reg }}\right)$ for the copper complexes are calculated using

$$
\Phi_{\text {reg }}=\frac{k_{\text {reg }}}{k_{\text {reg }}+k_{\text {rec }}} \approx 1-\frac{\tau_{1 / 2, \text { redox }}}{\tau_{1 / 2 \text {,inert }}}
$$

For all the copper electrolytes, the $\Phi_{\text {reg }}$ values are found to be close to $100 \%$. For the Y123 dye, the regeneration efficiencies 
of cobalt $\left(\left[\mathrm{Co}(\text { bpy-pz })_{2}\right]^{3+/ 2+}\right)(0.86 \mathrm{~V}$ vs SHE $)$ and iodide/triiodide ( $0.37 \mathrm{~V}$ vs SHE) electrolytes were previously reported to be 0.93 and 0.98 , respectively, based on $1.1 \mathrm{~ms}$ half-time for oxidized dye signal decay. ${ }^{10}$ We can conclude that with a relatively low driving force for dye regeneration, the $\mathrm{Cu}$ complexes investigated in this study provide faster kinetics compared to those of previously reported systems. The comparison of regeneration efficiencies with previously reported values for cobalt and iodide/tri-iodide indicates a better dye regeneration for copper complexes.

\section{CONCLUSIONS}

In this work, the conventional iodide/tri-iodide or cobalt based electrolytes for DSCs have very successfully been replaced with $\mathrm{Cu}^{(\mathrm{II} / \mathrm{I})}(\mathrm{dmby})_{2} \mathrm{TFSI}_{2 / 1}(0.97 \mathrm{~V}$ vs $\mathrm{SHE})$ and $\mathrm{Cu}^{(\mathrm{II} / \mathrm{I})}\left(\mathrm{tmby}_{2} \mathrm{TFSI}_{2 / 1}(0.87 \mathrm{~V}\right.$ vs SHE$)$ complexes. These copper complexes were compared to the previously reported $\left[\mathrm{Cu}(\mathrm{dmp})_{2}\right]^{2+/ 1+}$ complex by using the Y123 dye. Because of the high redox potentials of the copper electrolytes, the potential used for dye regeneration is minimized. With the given ligand structures providing small reorganization energies, the copper electrolytes are able to regenerate oxidized dye molecules with values close to unit yield even with relatively low driving forces. With the optimized devices, 10.2, 10.1, and $10.2 \%$ overall solar-to-electrical power efficiencies were recorded for $\left[\mathrm{Cu}(\mathrm{tmby})_{2}\right]^{2+/ 1+},\left[\mathrm{Cu}(\mathrm{dmby})_{2}\right]^{2+/ 1+}$, and $[\mathrm{Cu}-$ $\left.(\mathrm{dmp})_{2}\right]^{2+/ 1+}$ based electrolytes, respectively, under $1000 \mathrm{~W}$ $\mathrm{m}^{-2}$ AM1.5G illumination. The photocurrent voltages are higher than $1000 \mathrm{mV}$, indicating reduced potential losses in the devices. The efficient regeneration at minimized driving forces open up possibilities for increasing DSC record efficiencies. Since the photovoltage remain high, above $1 \mathrm{~V}$ down to 0.2 sun light intensity, we anticipate these $\mathrm{Cu}$-complex based DSCs to be particularly attractive for indoor applications. It is also clear that with an improved fill factor through a better counter electrode material the PCE values could be improved further.

\section{ASSOCIATED CONTENT}

\section{S Supporting Information}

The Supporting Information is available free of charge on the ACS Publications website at DOI: 10.1021/jacs.6b10721.

Synthetic procedures, cyclic voltammograms, UV-vis spectra, methods and computational details, HOMO/ LUMO structures, TD-DFT results, current density versus applied potential curves, and minimum-energy structures of the $\mathrm{Cu}$ complexes in acetonitrile solution (PDF)

\section{AUTHOR INFORMATION}

\section{Corresponding Author}

*marina.freitag@epfl.ch

\section{Notes}

The authors declare no competing financial interest.

\section{ACKNOWLEDGMENTS}

We acknowledge Swiss National Science Foundation for financial support with the project entitled as "Fundamental studies of mesoscopic devices for solar energy conversion" with project number 200021_157135/1. L.K. acknowledges support from the Grant Agency of the Czech Republic (contract No. 13-07724S). We thank Paul Liska, Peter Pechy, and Pascal Comte for their technical support.

\section{REFERENCES}

(1) O’Regan, B.; Grätzel, M. Nature 1991, 353 (6346), 737.

(2) Hagfeldt, A.; Boschloo, G.; Sun, L.; Kloo, L.; Pettersson, H. Chem. Rev. 2010, 110, 6595.

(3) Tian, H.; Sun, L. J. Mater. Chem. 2011, 21 (29), 10592.

(4) Yu, Z.; Vlachopoulos, N.; Gorlov, M.; Kloo, L. Dalt. Trans. 2011 , 40 (40), 10289.

(5) Feldt, S. M.; Gibson, E. A.; Gabrielsson, E.; Sun, L.; Boschloo, G.; Hagfeldt, A. J. Am. Chem. Soc. 2010, 132 (46), 16714.

(6) Yella, a.; Lee, H.-W.; Tsao, H. N.; Yi, C.; Chandiran, a. K.; Nazeeruddin, M. K.; Diau, E. W.-G.; Yeh, C.-Y.; Zakeeruddin, S. M.; Grätzel, M. Science (Washington, DC, U. S.) 2011, 334 (6056), 629.

(7) Mathew, S.; Yella, A.; Gao, P.; Humphry-baker, R.; Curchod, B. F. E.; Ashari-astani, N.; Tavernelli, I.; Rothlisberger, U.; Nazeeruddin, K.; Grätzel, M. Nat. Chem. 2014, 6, 242.

(8) Kakiage, K.; Aoyama, Y.; Yano, T.; Oya, K.; Fujisawa, J.; Hanaya, M. Chem. Commun. 2015, 51 (88), 15894.

(9) Mosconi, E.; Yum, J. H.; Kessler, F.; Gómez García, C. J. G.; Zuccaccia, C.; Cinti, A.; Nazeeruddin, M. K.; Grätzel, M.; De Angelis, F. J. Am. Chem. Soc. 2012, 134 (47), 19438.

(10) Yum, J.-H.; Baranoff, E.; Kessler, F.; Moehl, T.; Ahmad, S.; Bessho, T.; Marchioro, A.; Ghadiri, E.; Moser, J.-E.; Yi, C.; Nazeeruddin, M. K.; Grätzel, M. Nat. Commun. 2012, 3, 631.

(11) Feldt, S. M.; Wang, G.; Boschloo, G.; Hagfeldt, A. J. Phys. Chem. C 2011, 115 (43), 21500.

(12) Feldt, S. M.; Lohse, P. W.; Kessler, F.; Nazeeruddin, M. K.; Grätzel, M.; Boschloo, G.; Hagfeldt, A. Phys. Chem. Chem. Phys. 2013, 15 (19), 7087.

(13) Nelson, J. J.; Amick, T. J.; Elliott, C. M. J. Phys. Chem. C 2008, 112,18255

(14) Klahr, B. M.; Hamann, T. W. J. Phys. Chem. C 2009, 113 (31), 14040.

(15) Sapp, S. A.; Elliott, C. M.; Contado, C.; Caramori, S.; Bignozzi, C. A. J. Am. Chem. Soc. 2002, 124 (37), 11215.

(16) Gao, J.; Bhagavathi Achari, M.; Kloo, L. Chem. Commun. (Cambridge, U. K.) 2014, 50 (47), 6249.

(17) Kashif, M. K.; Nippe, M.; Duffy, N. W.; Forsyth, C. M.; Chang, C. J.; Long, J. R.; Spiccia, L.; Bach, U. Angew. Chem., Int. Ed. 2013, 52 (21), 5527.

(18) Bai, Y.; Yu, Q.; Cai, N.; Wang, Y.; Zhang, M.; Wang, P. Chem. Commun. 2011, 47 (15), 4376.

(19) Hattori, S.; Wada, Y.; Yanagida, S.; Fukuzumi, S. J. Am. Chem. Soc. 2005, 127 (26), 9648.

(20) Brugnati, M.; Caramori, S.; Cazzanti, S.; Marchini, L.; Argazzi, R.; Bignozzi, C. A. Int. J. Photoenergy 2007, 1.

(21) Cong, J.; Kinschel, D.; Daniel, Q.; Safdari, M.; Gabrielsson, E.; Chen, H.; Svensson, P. H.; Sun, L.; Kloo, L. J. Mater. Chem. A 2016, 4 (38), 14550.

(22) Constable, E. C.; Redondo, A. H.; Housecroft, C. E.; Neuburger, M.; Schaffner, S. Dalt. Trans. 2009, No. 33, 6634.

(23) Freitag, M.; Giordano, F.; Yang, W.; Pazoki, M.; Hao, Y.; Zietz, B.; Grätzel, M.; Hagfeldt, A.; Boschloo, G. J. Phys. Chem. C 2016, 120, 9595.

(24) Tsao, H. N.; Yi, C.; Moehl, T.; Yum, J.; Zakeeruddin, S. M.; Nazeeruddin, M. K.; Grätzel, M. ChemSusChem 2011, 4, 591.

(25) McCusker, C. E.; Castellano, F. N. Inorg. Chem. 2013, 52 (14), 8114.

(26) Gothard, N. A.; Mara, M. W.; Huang, J.; Szarko, J. M.; Rolczynski, B.; Lockard, J. V.; Chen, L. X. J. Phys. Chem. A 2012, 116 (9), 1984

(27) Buckner, M. T.; McMillin, D. R. J. Chem. Soc., Chem. Commun. 1978, No. 17, 759.

(28) Freitag, M.; Daniel, Q.; Pazoki, M.; Sveinbjörnsson, K.; Zhang, J.; Sun, L.; Hagfeldt, A.; Boschloo, G. Energy Environ. Sci. 2015, 8 (9), 2634.

(29) Ellis, H.; Vlachopoulos, N.; Häggman, L.; Perruchot, C.; Jouini, M.; Boschloo, G.; Hagfeldt, A. Electrochim. Acta 2013, 107, 45.

(30) Hoffeditz, W. L.; Katz, M. J.; Deria, P.; Cutsail, G. E.; Pellin, M. J.; Farha, O. K.; Hupp, J. T. J. Phys. Chem. C 2016, 120, 3731. 
(31) Frisch, M. J.; Trucks, G. W.; Schlegel, H. B.; Scuseria, G. E.; Robb, M. A.; Cheeseman, J. R.; Scalmani, G.; Barone, V.; Mennucci, B.; Petersson, G. A.; Nakatsuji, H.; Caricato, M.; Li, X.; Hratchian, H. P.; Izmaylov, A. F.; Bloino, J.; Zheng, G.; Sonnenberg, J. L.; Hada, M.; Ehara, M.; Toyota, K.; Fukuda, R.; Hasegawa, J.; Ishida, M.; Nakajima, T.; Honda, Y.; Kitao, O.; Nakai, H.; Vreven, T.; Montgomery, J. A., Jr.; Peralta, J. E.; Ogliaro, F.; Bearpark, M.; Heyd, J. J.; Brothers, E.; Kudin, K. N.; Staroverov, V. N.; Kobayashi, R.; Normand, J.; Raghavachari, K.; Rendell, A.; Burant, J. C.; Iyengar, S. S.; Tomasi, J.; Cossi, M.; Rega, N.; Millam, J. M.; Klene, M.; Knox, J. E.; Cross, J. B.; Bakken, V.; Adamo, C.; Jaramillo, J.; Gomperts, R.; Stratmann, R. E.; Yazyev, O.; Austin, A. J.; Cammi, R.; Pomelli, C.; Ochterski, J. W.; Martin, R. L.; Morokuma, K.; Zakrzewski, V. G.; Voth, G. A.; Salvador, P.; Dannenberg, J. J.; Dapprich, S.; Daniels, A. D.; Farkas, O.; Foresman, J. B.; Ortiz, J. V.; Cioslowski, J.; Fox, D. J. Gaussian 09, revision E.01; Gaussian, Inc.: Wallingford, CT, 2009.

(32) Adamo, C.; Barone, V. J. Chem. Phys. 1999, 110 (13), 6158.

(33) Tomasi, J.; Mennucci, B.; Cammi, R. Chem. Rev. 2005, 105 (8), 2999.

(34) Marenich, A. V.; Cramer, C. J.; Truhlar, D. G. J. Phys. Chem. B 2009, 113 (18), 6378.

(35) Scalmani, G.; Frisch, M. J.; Mennucci, B.; Tomasi, J.; Cammi, R.; Barone, V. J. Chem. Phys. 2006, 124 (9), 094107.

(36) Sun, Z.; Zheng, K.; Li, Q.; Li, Z. RSC Adv. 2014, 4, 31544.

(37) Ørnsø, K. B.; Jónsson, E. Ö.; Jacobsen, K. W.; Thygesen, K. S. J. Phys. Chem. C 2015, 119 (23), 12792.

(38) Cameron, P. J.; Peter, L. M. J. Phys. Chem. B 2003, 107 (51), 14394.

(39) Cappel, U. B.; Feldt, S. M.; Schöneboom, J.; Hagfeldt, A.; Boschloo, G. J. Am. Chem. Soc. 2010, 132 (26), 9096.

(40) Ardo, S.; Sun, Y.; Staniszewski, A.; Castellano, F. N.; Meyer, G. J. J. Am. Chem. Soc. 2010, 132 (19), 6696. 


\section{SUPPORTING INFORMATION}

\section{Copper Bipyridyl Redox Mediators for Dye-Sensitized Solar Cells with High Photovoltage}

Yasemin Saygili, Magnus Söderberg, Norman Pellet, Fabrizio Giordano, Yiming Cao, Ana Belen Muñoz-García, Shaik M. Zakeeruddin, Nick Vlachopoulos, Michele Pavone, Gerrit Boschloo, Ladislav Kavan, Jacques-E. Moser, Michael Grätzel, Anders Hagfeldt and Marina Freitag

\section{Synthesis of copper $2,2^{\prime}$-dimethyl phenanthroline $\left(\mathrm{Cu}^{(\mathrm{I} / \mathrm{II})}(\mathrm{dmp})_{2} \mathrm{TFSI}_{1 / 2}\right)(1,2)$} $\mathrm{Cu}^{(\mathrm{I} / \mathrm{II})}(\mathrm{dmp})_{2}$ TFSI $_{1 / 2}(\mathbf{1 , 2})$ Figure S 1.

For $\left(\mathrm{Cu}(\mathrm{dmp})_{2} \mathrm{TFSI}\right)(\mathbf{1}), 1$ eq. of $\mathrm{CuI}(35 \mathrm{mg}, 0.175 \mathrm{mmol})$ was mixed with 4 eq. of Neocuproine hydrate $(100 \mathrm{mg}, 0.7 \mathrm{mmol})$ in ethanol, under nitrogen atmosphere, at room temperature for 2 hours. Complex (1) was collected by filtration and washed with water and diethyl ether. The resulted complex (1) was obtained as intense red, crystalline powder. The yield was $90 \%(0.16 \mathrm{mmol})$.

For $\mathrm{Cu}(\mathrm{dmp})_{2} \mathrm{TFSI}_{2}(2)$, Complex (1) $(100 \mathrm{mg}, 0.13 \mathrm{mmol})$ was dissolved in acetonitrile. To this solution, 1 equivalent of $\mathrm{NOBF}_{4}(16 \mathrm{mg}, 0.13 \mathrm{mmol})$ followed by 5 equivalents of LiTFSI ( $37 \mathrm{mg}, 0.65 \mathrm{mmol})$ were added after $30 \mathrm{~min}$. The solution was further stirred for 2 hours at room temperature and under nitrogen atmosphere. The solvent was removed by rotatory evaporation and the crude redissolved in minimum amount of dichloromethane. Complex (2) was collected by filtration after precipitation from diethylether and washed with diethyl ether. The yield was $72 \%$ (0.09 mmol). The product was a bright violet powder.

${ }^{1} \mathrm{H}$ NMR (400 MHz, acetone d6): $\delta 8.75(\mathrm{~d}, J(\mathrm{H}-\mathrm{H})=8.21 \mathrm{~Hz}, 1 \mathrm{H}), 8.23(\mathrm{~s}, 1 \mathrm{H}), 7.98$

$(\mathrm{d}, J(\mathrm{H}-\mathrm{H})=8.24 \mathrm{~Hz}, 1 \mathrm{H}), 2.52(\mathrm{~s}, 3 \mathrm{H})$. MALDI-MS: (1) $\mathrm{m} / \mathrm{z}(\%) 473.132$ $(90)\left(\left[\mathrm{Cu}(\mathrm{dmp})_{2} \mathrm{TFSI}^{+}\right) ;(2) \mathrm{m} / \mathrm{z}(\%) 479.182(90)\left(\left[\mathrm{Cu}(\mathrm{dmp})_{2} \mathrm{TFSI}^{2+}\right)\right.\right.$ 

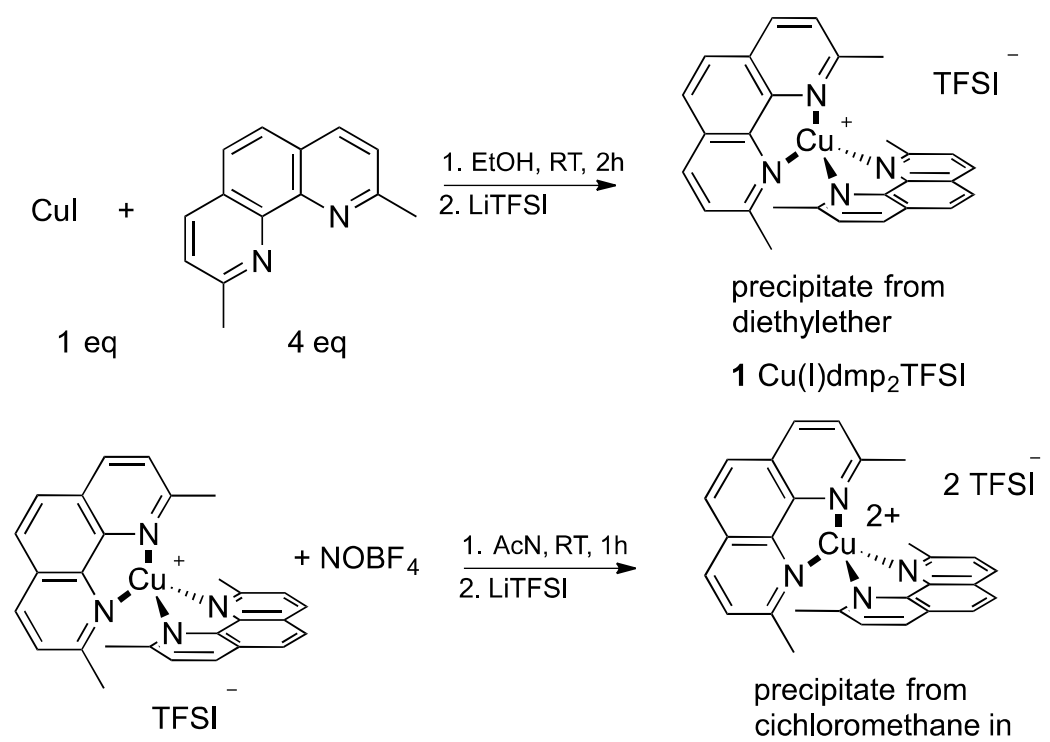

$$
\begin{aligned}
& \text { precipitate from } \\
& \text { cichloromethane in } \\
& \text { diethylether } \\
& 2 \mathrm{Cu}(\mathrm{II}) \mathrm{dmp}_{2} \mathrm{TFSI}_{2}
\end{aligned}
$$

$$
\text { TFSI = trifluoromethanesulfonimide }
$$

Figure S 1 Synthetic procedure for $\mathrm{Cu}^{(\mathrm{I} / \mathrm{II})}(\mathrm{dmp})_{2} \mathrm{TFSI}_{1 / 2}$

\section{Synthesis of copper complexes: 6,6'-dimethyl-2,2'-bipyridine}

$\left(\mathrm{Cu}^{(\mathrm{I} / \mathrm{II})}(\mathrm{dmby})_{2} \mathrm{TFSI}_{1 / 2}\right)(3,4)$ and 4,4',6,6'-tetramethyl-2,2'-bipyridine $\left(\mathrm{Cu}^{(\mathrm{I} / \mathrm{II})}\left(\mathrm{tmby}_{2} \mathrm{TFSI}_{1 / 2}\right) \quad(5,6) \quad \mathrm{Cu}^{(\mathrm{I} / \mathrm{II})}(\mathrm{dmby})_{2} \mathrm{TFSI}_{1 / 2} \quad\right.$ or $\left(\mathrm{Cu}^{(\mathrm{I} / \mathrm{II})}(\mathrm{tmby})_{2} \mathrm{TFSI}_{1 / 2}\right)$

\section{$(3,5)$ (Figure S 2):}

For $\left(\mathbf{C u}(\mathbf{d m b y})_{2}\right.$ TFSI) and $\left(\mathbf{C u}(\mathrm{tmby})_{2}\right.$ TFSI $)(\mathbf{3 , 5})$, one equivalent of $\mathrm{CuI}(35 \mathrm{mg}$, $0.175 \mathrm{mmol}$ ) was mixed with 3 equivalents of 6,6'-dimethyl-2,2'-bipyridine (120 mg, $0.7 \mathrm{mmol})$ or $4,4^{\prime}, 6,6$ '-tetramethyl-2,2'-bipyridine $(150 \mathrm{mg}, 0.7 \mathrm{mmol})$ in $20 \mathrm{ml}$ ethanol, under nitrogen atmosphere, at room temperature for 2 hours. The resulted complex (1) was obtained as intense red, crystalline powder. The product was filtered and redissolved by addition of $5 \mathrm{ml}$ of deionized water followed by an addition of 5 equivalents of LiTFSI (37 mg, $0.65 \mathrm{mmol}$ ). The solution was further stirred for 2 hours at room temperature and under nitrogen atmosphere resulting in red precipitation. The complex $(\mathbf{3 , 5})$ was collected by filtration and washed with water. 
The yield of the products was $80 \%$ (mol). In both cases product was a bright red powder.

${ }^{1} \mathrm{H}$ NMR (400 MHz, acetone d6): $\delta 8.75(\mathrm{~d}, J(\mathrm{H}-\mathrm{H})=8.21 \mathrm{~Hz}, 1 \mathrm{H}), 8.23(\mathrm{~s}, 1 \mathrm{H}), 7.98$ $(\mathrm{d}, J(\mathrm{H}-\mathrm{H})=8.24 \mathrm{~Hz}, 1 \mathrm{H}), 2.52(\mathrm{~s}, 3 \mathrm{H})$. MALDI-MS: (3) m/z (\%) 431.124 (90)([Cu(dmby $\left.)_{2} \mathrm{TFSI}^{+}\right) ;(\mathbf{5}) \mathrm{m} / \mathrm{z}(\%) 487.188(90)\left(\left[\mathrm{Cu}(\mathrm{tmby})_{2} \mathrm{TFSI}^{+}\right)\right.$

For $\left(\mathbf{C u}(\mathbf{d m b y})_{2} \mathbf{T F S I}_{2}\right)(4)$ or $\left(\mathbf{C u}(\mathbf{t m b y})_{2} \mathbf{T F S I}_{2}\right)(6)$ : One equivalent of $\mathrm{CuCl}_{2}(35$ $\mathrm{mg}, 0.175 \mathrm{mmol}$ ) was mixed with 3 equivalents of 6,6'-dimethyl-2,2'-bipyridine (120 $\mathrm{mg}, 0.7 \mathrm{mmol}$ ) or 4,4',6,6'-tetramethyl-2,2'-bipyridine (150 mg, $0.7 \mathrm{mmol})$ in $20 \mathrm{ml}$ ethanol, under nitrogen atmosphere, at room temperature for 2 hours. The resulted complex (1) was obtained as green powder. The product was filtered and redissolved by addition of $5 \mathrm{ml}$ of deionized water followed by an addition of 5 equivalents of LiTFSI $(37 \mathrm{mg}, 0.65 \mathrm{mmol})$. The solution was further stirred for 2 hours at room temperature and under nitrogen atmosphere resulting in green precipitation. The complex $(3,5)$ was collected by filtration and washed with water. The average yield was $70 \%$ (mol). The products were green powders.

${ }^{1} \mathrm{H}$ NMR (400 MHz, acetone d6): $\delta 8.75(\mathrm{~d}, J(\mathrm{H}-\mathrm{H})=8.21 \mathrm{~Hz}, 1 \mathrm{H}), 8.23(\mathrm{~s}, 1 \mathrm{H}), 7.98$ $(\mathrm{d}, J(\mathrm{H}-\mathrm{H})=8.24 \mathrm{~Hz}, 1 \mathrm{H}), 2.52(\mathrm{~s}, 3 \mathrm{H})$. MALDI-MS: (4) m/z (\%) 431.129 (90) $\left(\left[\mathrm{Cu}(\mathrm{dmby})_{2} \mathrm{TFSI}\right]^{2+}\right) ;(\mathbf{6}) \mathrm{m} / \mathrm{z}(\%) 487.197(90)\left(\left[\mathrm{Cu}(\mathrm{tmby})_{2} \mathrm{TFSI}\right]^{2+}\right)$ 

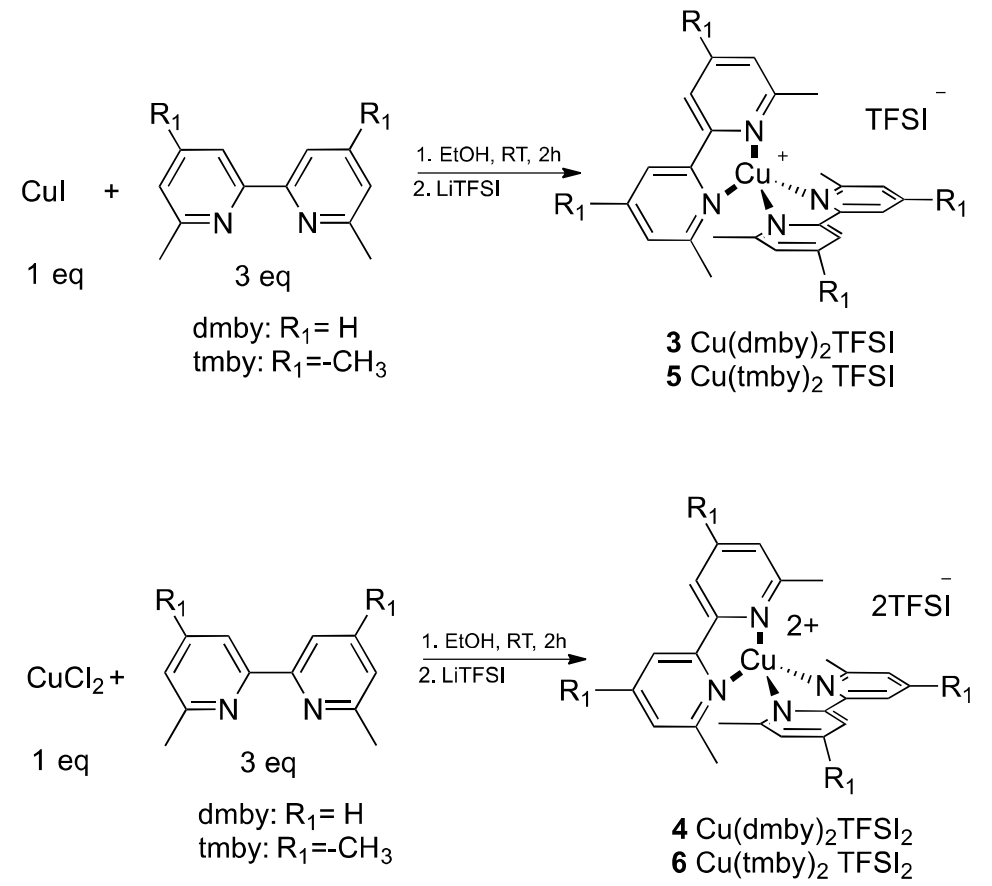

Figure $\mathrm{S} 2$ Synthetic procedure for $\left.\mathrm{Cu}^{(\mathrm{I} / \mathrm{II})}(\mathrm{dmby})_{2} \mathrm{TFSI}_{1 / 2}\right) \quad(3,4)$ and $\left(\mathrm{Cu}^{(\mathrm{I} / \mathrm{II})}(\mathrm{tmby})_{2} \mathrm{TFSI}_{1 / 2}\right)(5,6)$

\section{Cyclic voltammograms}

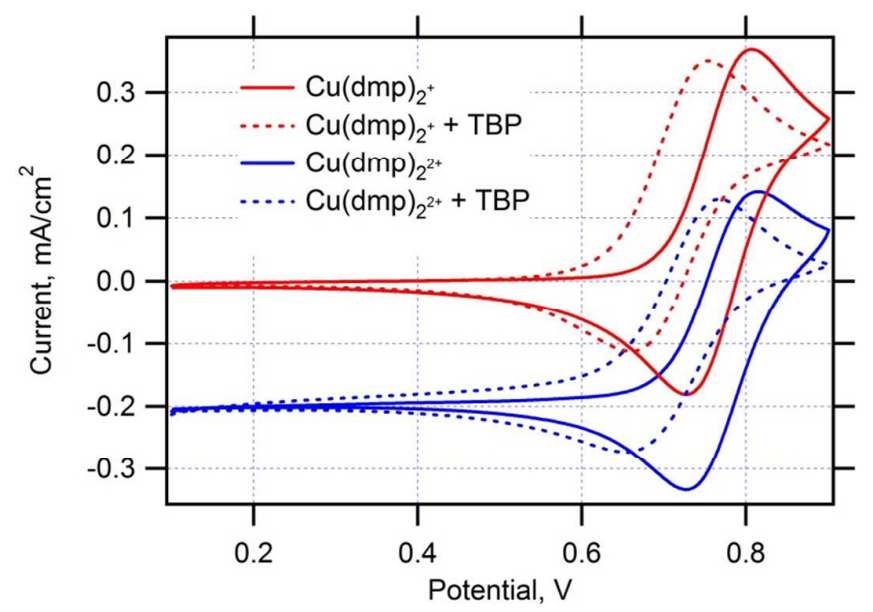

Figure S 3.a. Cyclic voltammograms of $5 \mathrm{mM}$ solutions of $\mathrm{Cu}(\mathrm{dmp})_{2}{ }^{+}$TFSI (red curves) and $\mathrm{Cu}(\mathrm{dmp})_{2}{ }^{2+} \mathrm{TFSI}_{2}$ (blue curves) in $0.1 \mathrm{M}$ LiTFSI/acetonitrile. Scan rate $10 \mathrm{mV} / \mathrm{s}$. Dashed lines are voltammograms of the same species but after adding 4-tert-butylpyridine (12.5 mM concentration). Potentials are referenced 
to the $\mathrm{Ag} / \mathrm{AgCl}$ (sat'd $\mathrm{LiCl}$ in ethanol) reference electrode. A standard ferrocene couple was $0.469 \mathrm{~V}$ vs. $\mathrm{Ag} / \mathrm{AgCl}$ (with no significant influence of TBP addition).

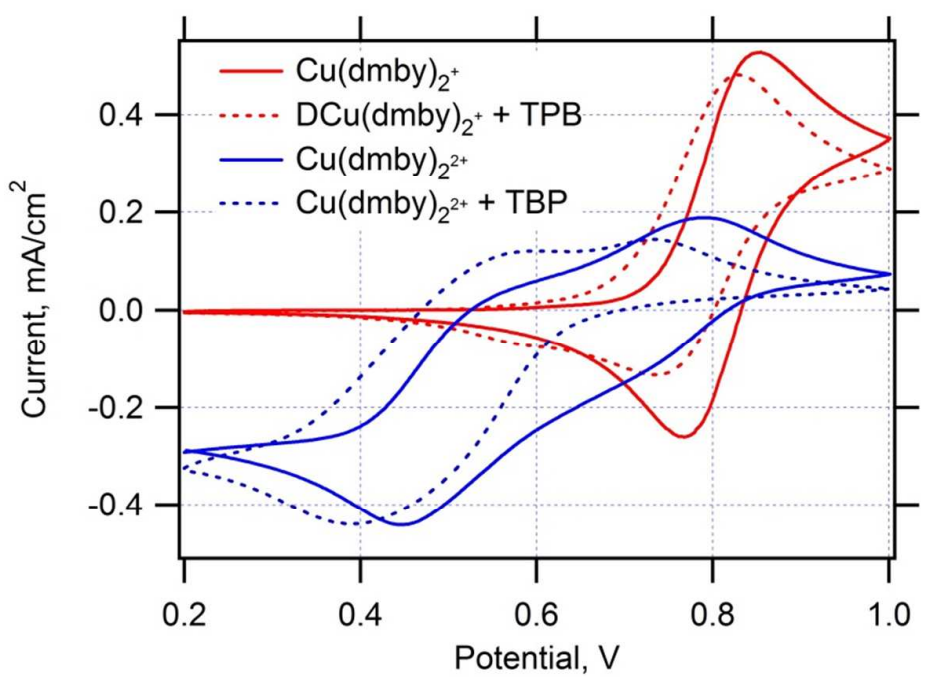

Figure S 3. b. Cyclic voltammograms of $5 \mathrm{mM}$ solutions of $\mathrm{Cu}(\mathrm{dmby})_{2}{ }^{+}{ } \mathrm{TFSI}$ (red curves) and $\mathrm{Cu}(\mathrm{dmby})_{2}{ }^{2+} \mathrm{TFSI}_{2}$ (blue curves) in $0.1 \mathrm{M}$ LiTFSI/acetonitrile. Scan rate $10 \mathrm{mV} / \mathrm{s}$. Dashed lines are voltammograms of the same species but after adding 4-tert-butylpyridine (12.5 mM concentration). Potentials are referenced to the $\mathrm{Ag} / \mathrm{AgCl}$ (sat'd $\mathrm{LiCl}$ in ethanol) reference electrode. A standard ferrocene couple was $0.468 \mathrm{~V}$ vs. $\mathrm{Ag} / \mathrm{AgCl}$ (with no significant influence of TBP addition).

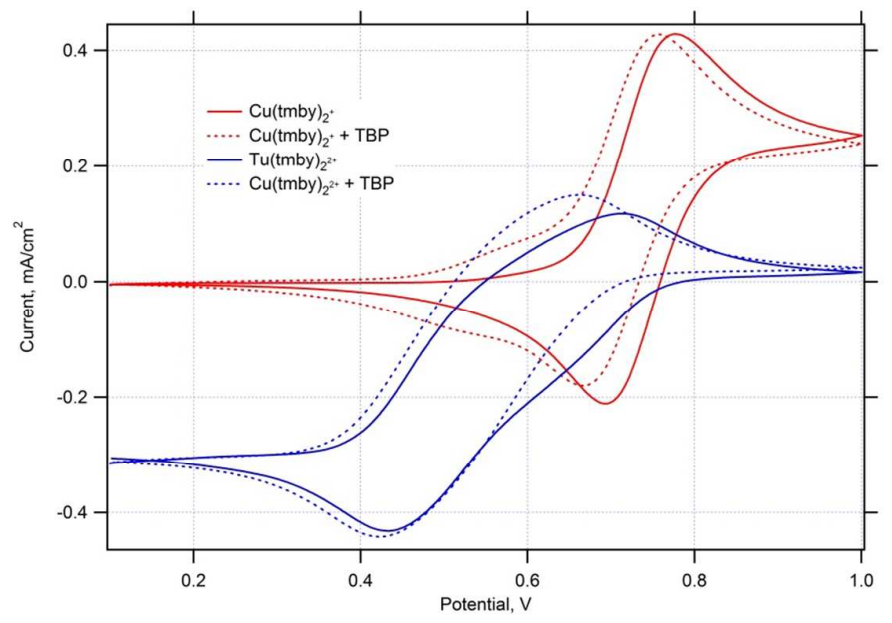

Figure S 3.c. Cyclic voltammograms of $5 \mathrm{mM}$ solutions of $\mathrm{Cu}(\mathrm{tmby})_{2}{ }^{+} \mathrm{TFSI}($ red curves) and $\mathrm{Cu}(\mathrm{dmby})_{2}{ }^{2+} \mathrm{TFSI}_{2}$ (blue curves) in $0.1 \mathrm{M}$ LiTFSI/acetonitrile. Scan 
rate $10 \mathrm{mV} / \mathrm{s}$. Dashed lines are voltammograms of the same species but after adding 4-tert-butylpyridine (12.5 $\mathrm{mM}$ concentration). Potentials are referenced to the $\mathrm{Ag} / \mathrm{AgCl}$ (sat'd $\mathrm{LiCl}$ in ethanol) reference electrode. A standard ferrocene couple was $0.471 \mathrm{~V}$ vs. $\mathrm{Ag} / \mathrm{AgCl}$ (with no significant influence of TBP addition).
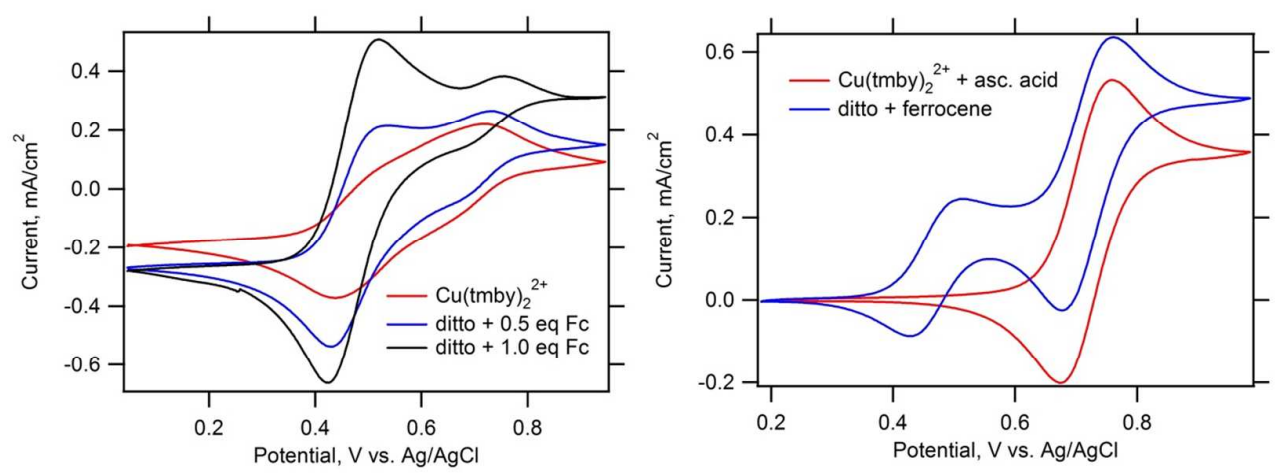

Figure S4: Right chart: Cyclic voltammograms of $5 \mathrm{mM}$ solutions of $\mathrm{Cu}(\mathrm{tmby})_{2}{ }^{2+} \mathrm{TFSI}_{2}$ (red curves) and the same complex after addition of 0.5 or 1 equivalents of ferrocene (blue or black curves, respectively) in $0.1 \mathrm{M}$ LiTFSI/acetonitrile. Left chart: product of chemical oxidation of $\mathrm{Cu}(\text { tmby })_{2}{ }^{2+} \mathrm{TFSI}_{2}$ by ascorbic acid (blue corve is for the same solution after adding ferrocene). Scan rate $10 \mathrm{mV} / \mathrm{s}$.

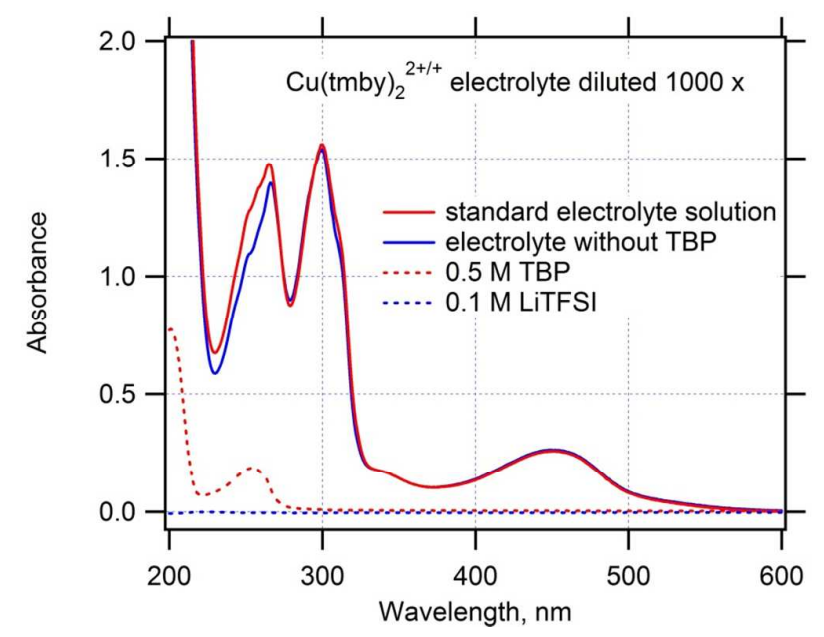

Figure S5. UV-Vis spectrum of the actual electrolyte solution (diluted $1000 \mathrm{x}$ with acetonitrile). For comparison, the spectra of individual components are 
shown too. The actual working electrolyte solutions prepared without TBP is displayed by blue curve. Optical cell thickness $2 \mathrm{~mm}$.

\section{Methods and computational details}

All the calculations have been performed with the G09 suite of programs for quantum chemistry.

The PBE0 hybrid DFT approach has been applied in all the calculations together with SDD ECP-basis set for $\mathrm{Cu}$ and TZVP basis set for $\mathrm{C}, \mathrm{H}$ and $\mathrm{N}$ atoms.

The acetonitrile solvent is described by the PCM implicit solvation model with the last parameterization of non-empirical solvation term known as SMD.

Vertical excitation energies are computed with the TD-DFT approach by considering the non-equilibrium PCM model to include the solvent effects.

Ground-state minimum-energy structures have been computed considering the default maximum force and displacement tolerance parameters in Gaussian. Molecular frequencies have been computed within the harmonic oscillator approximation, and the thermochemical data are derived at room temperature $(298 \mathrm{~K})$ and considering the most common atom isotopes.

Internal reorganization energies $\left(\lambda_{\text {in }}\right)$ have been computed with a common approach by considering the $\mathrm{Cu}(\mathrm{I}) \mathrm{L}_{2}$ and $\mathrm{Cu}(\mathrm{II}) \mathrm{L}_{2}$ minimum-energy structures in solution. $\lambda_{\text {in }}$ is evaluated in the gas phase as the energy differences of $\mathrm{Cu}(\mathrm{I})$ complexes evaluated at the relaxed geometries that correspond to the initial and final electronic states. 

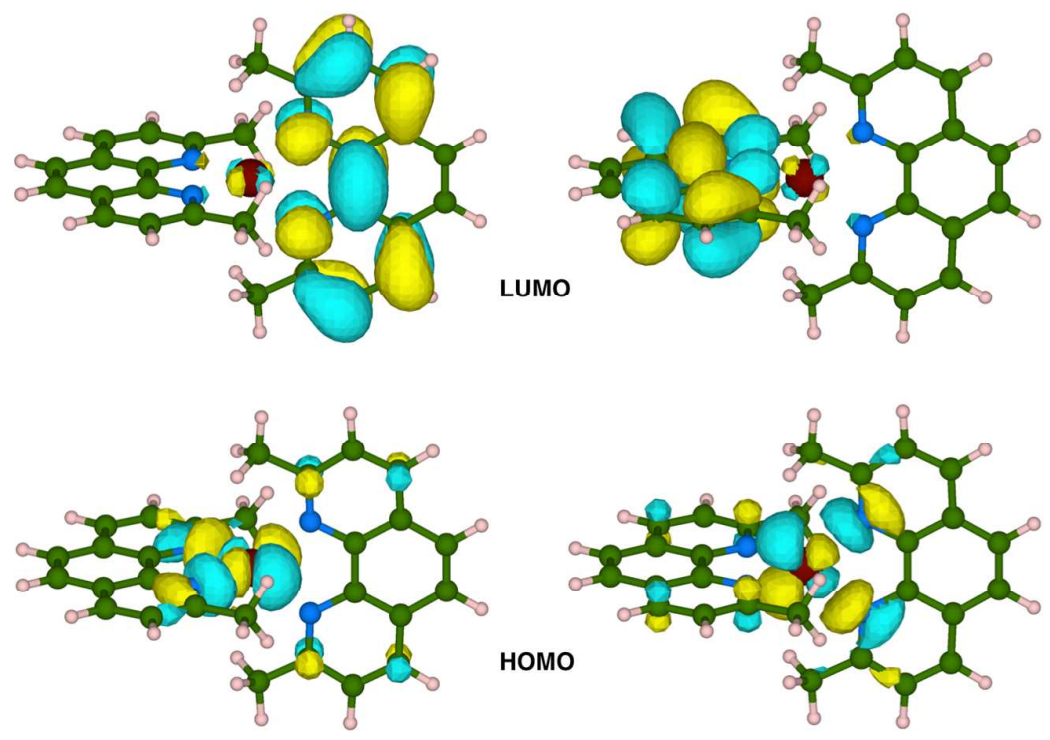

Figure S 6. Frontier molecular orbitals (HOMO and LUMO) for $\mathrm{Cu}(\mathrm{I})(\mathrm{dmp})_{2}$.
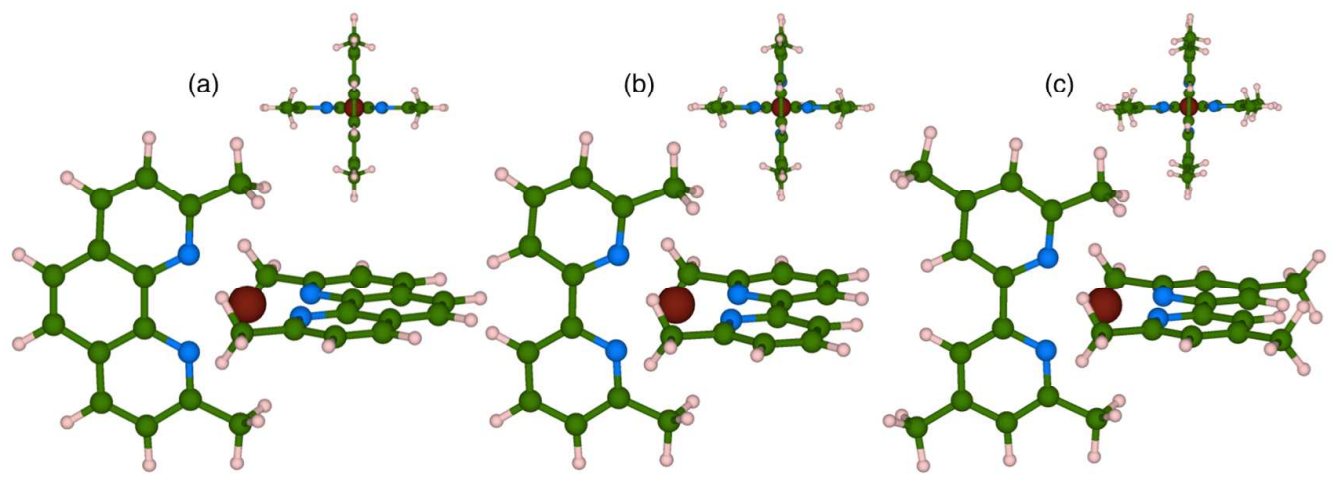

Figure $S$ 7. $C u(I) L_{2}$ minimum-energy structures, $L$ is dmp (a), dmby (b) and tmby (c).

Table S1. TD-DFT results: first vertical excitation energies $\left(\Delta E_{\text {exc }}\right)$ and corresponding oscillator strength $(f)$ in acetonitrile solution.

\begin{tabular}{|l|c|c|}
\hline & $\Delta \mathrm{E}_{\text {exc }}(\mathrm{nm})$ & $f$ \\
\hline $\mathrm{Cu}(\mathrm{dmp})_{2}{ }^{1+}$ & 466 & 0.1996 \\
\hline $\mathrm{Cu}(\mathrm{dmby})_{2}{ }^{1+}$ & 474 & 0.1722 \\
\hline $\mathrm{Cu}(\mathrm{dmp})_{2}{ }^{1+}$ & 463 & 0.1903 \\
\hline
\end{tabular}


Table S 2. Geometrical features of the minimum-energy structures for $\mathrm{CuL}_{2}$ ( $L=d m p$, dmpy, tmby) complexes in acetonitrile solution.

\begin{tabular}{|c|c|c|c|}
\hline & $d m p$ & $d m b y$ & $t m b y$ \\
\hline \multicolumn{4}{|l|}{$\mathrm{Cu}(\mathrm{I})$ complexes } \\
\hline distance $\mathrm{Cu}-\mathrm{N}(\AA)$ & 2.074 & 2.068 & 2.067 \\
\hline angle $\mathrm{N}_{1}-\mathrm{Cu}-\mathrm{N}_{2}\left(^{\circ}\right)$ & 81.0 & 80.0 & 80.0 \\
\hline dihedral $\mathrm{N}_{1}-\mathrm{C}_{1}-\mathrm{C}_{2}-\mathrm{N}_{2}\left(^{\circ}\right)$ & 0.0 & 2.6 & 2.0 \\
\hline \multicolumn{4}{|l|}{$\mathrm{Cu}$ (II) complexes } \\
\hline distance $\mathrm{Cu}-\mathrm{N}(\AA)$ & 2.041 & 2.025 & 2.021 \\
\hline angle $\mathrm{N}_{1}-\mathrm{Cu}-\mathrm{N}_{2}\left({ }^{\circ}\right)$ & 81.8 & 81.2 & 81.3 \\
\hline dihedral $\mathrm{N}_{1}-\mathrm{N}_{2}-\mathrm{Cu}-\mathrm{N}_{1}{ }^{\prime}\left(^{\circ}\right)$ & 0.4 & 9.0 & 7.1 \\
\hline
\end{tabular}

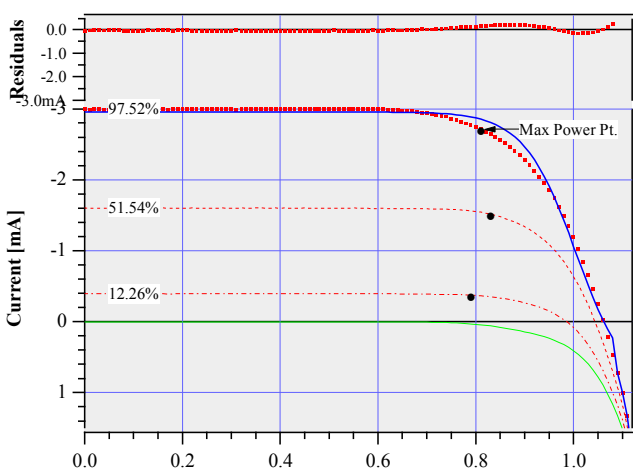

\begin{tabular}{|c|c|c|c|}
\hline Current $_{\text {ref }}$ & $\begin{array}{r}\mathbf{1 2 . 3 \%} \text { Sun } \\
-338.267 \mu \mathrm{A}\end{array}$ & $\begin{array}{l}\mathbf{5 1 . 5 \%} \text { Sun } \\
-1.422 \mathrm{~mA}\end{array}$ & $\begin{array}{l}\mathbf{9 7 . 5 \%} \text { Sun } \\
-2.691 \mathrm{~mA}\end{array}$ \\
\hline Power $_{\text {in }}$ & $12.256 \mathrm{~mW} / \mathrm{cm}^{2}$ & $51.537 \mathrm{~mW} / \mathrm{cm}^{2}$ & $97.517 \mathrm{~mW} / \mathrm{cm}^{2}$ \\
\hline $\begin{array}{l}\text { Norm. Std. Dev. } \\
\text { Module } U_{o c}\end{array}$ & $\begin{array}{l}0.19 \\
985.57 \mathrm{mV}\end{array}$ & $\begin{array}{l}0.17 \\
1.04 \mathrm{~V}\end{array}$ & $\begin{array}{l}0.16 \\
1.06 \mathrm{~V}\end{array}$ \\
\hline Cell $\mathrm{U}_{\mathrm{oc}}$ & $985.57 \mathrm{mV}$ & $1.04 \mathrm{~V}$ & $1.06 \mathrm{~V}$ \\
\hline $\mathrm{I}_{\mathrm{sc}}$ & $-394.624 \mu \mathrm{A}$ & $-1.608 \mathrm{~mA}$ & $-2.995 \mathrm{~mA}$ \\
\hline $\mathrm{J}_{\mathrm{sc}}$ & $-1.79 \mathrm{~mA} / \mathrm{cm}^{2}$ & $-7.31 \mathrm{~mA} / \mathrm{cm}^{2}$ & $-13.61 \mathrm{~mA} / \mathrm{cm}^{2}$ \\
\hline $\mathrm{U}_{\mathrm{pmax}}$ & $794.68 \mathrm{mV}$ & $833.78 \mathrm{mV}$ & $809.53 \mathrm{mV}$ \\
\hline$I_{p \max }$ & $-1.7 \mathrm{~mA} / \mathrm{cm}^{2}$ & $-6.9 \mathrm{~mA} / \mathrm{cm}^{2}$ & $-12.3 \mathrm{~mA} / \mathrm{cm}^{2}$ \\
\hline Power $_{\text {out }}$ & $1.35 \mathrm{~mW} / \mathrm{cm}^{2}$ & $5.73 \mathrm{~mW} / \mathrm{cm}^{2}$ & $9.99 \mathrm{~mW} / \mathrm{cm}^{2}$ \\
\hline Total Power ${ }_{\text {out }}$ & $297.47 \mu \mathrm{W}$ & $1.26 \mathrm{~mW}$ & $2.20 \mathrm{~mW}$ \\
\hline Fill Factor & 0.765 & 0.751 & 0.692 \\
\hline Efficiency $\eta$ & $11.03 \%$ & $11.11 \%$ & $10.25 \%$ \\
\hline
\end{tabular}

Figure S 8. Current density vs. applied potential curves for the best $\left[\mathrm{Cu}(\mathrm{dmp})_{2}\right]^{+1 /+2}$ device employing Y123 dye 

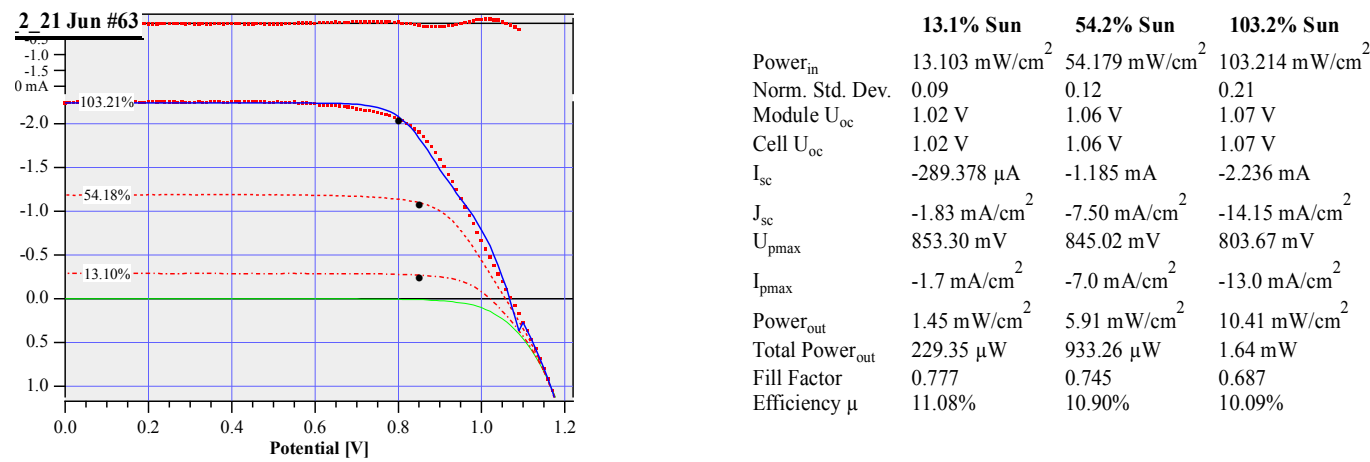

Figure S 9. Current density vs. applied potential curves for the best $\left[\mathrm{Cu}(\mathrm{dmby})_{2}\right]^{+1 /+2}$ device employing Y123 dye

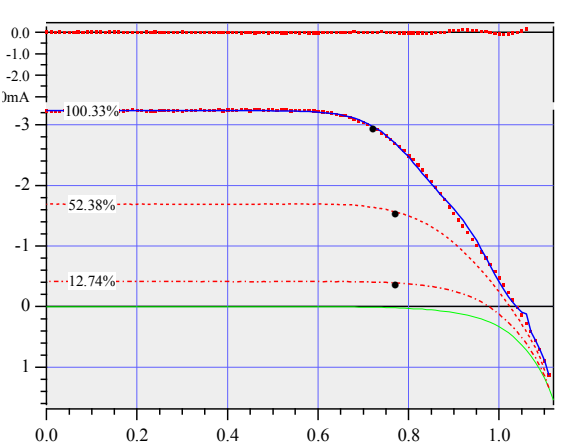

\begin{tabular}{|c|c|c|c|}
\hline Current $_{\text {ref }}$ & $\begin{array}{r}\text { 12.7\% Sun } \\
-353.785 \mu \mathrm{A}\end{array}$ & $\begin{array}{l}\mathbf{5 2 . 4 \%} \text { Sun } \\
-1.455 \mathrm{~mA}\end{array}$ & $\begin{array}{l}\mathbf{1 0 0 . 3 \%} \text { Sun } \\
-2.787 \mathrm{~mA}\end{array}$ \\
\hline Power $_{\text {in }}$ & $12.737 \mathrm{~mW} / \mathrm{cm}^{2}$ & $52.380 \mathrm{~mW} / \mathrm{cm}^{2}$ & $100.333 \mathrm{~mW} / \mathrm{cm}^{2}$ \\
\hline Norm. Std. Dev. & 0.11 & 0.14 & 0.17 \\
\hline Module $\mathrm{U}_{\mathrm{oc}}$ & $976.70 \mathrm{mV}$ & $1.02 \mathrm{~V}$ & $1.04 \mathrm{~V}$ \\
\hline Cell $U_{o c}$ & $976.70 \mathrm{mV}$ & $1.02 \mathrm{~V}$ & $1.04 \mathrm{~V}$ \\
\hline$I_{s c}$ & $-414.937 \mu \mathrm{A}$ & $-1.689 \mathrm{~mA}$ & $-3.416 \mathrm{~mA}$ \\
\hline $\mathrm{J}_{\mathrm{sc}}$ & $-1.89 \mathrm{~mA} / \mathrm{cm}^{2}$ & $-7.68 \mathrm{~mA} / \mathrm{cm}^{2}$ & $-15.53 \mathrm{~mA} / \mathrm{cm}^{2}$ \\
\hline $\mathrm{U}_{\mathrm{p} \max }$ & $774.68 \mathrm{mV}$ & $767.05 \mathrm{mV}$ & $726.05 \mathrm{mV}$ \\
\hline$I_{p \max }$ & $-1.8 \mathrm{~mA} / \mathrm{cm}^{2}$ & $-7.1 \mathrm{~mA} / \mathrm{cm}^{2}$ & $-14.2 \mathrm{~mA} / \mathrm{cm}^{2}$ \\
\hline Power $_{\text {out }}$ & $1.37 \mathrm{~mW} / \mathrm{cm}^{2}$ & $5.47 \mathrm{~mW} / \mathrm{cm}^{2}$ & $10.30 \mathrm{~mW} / \mathrm{cm}^{2}$ \\
\hline Total Power ${ }_{\text {out }}$ & $302.43 \mu \mathrm{W}$ & $1.20 \mathrm{~mW}$ & $2.27 \mathrm{~mW}$ \\
\hline Fill Factor & 0.746 & 0.696 & 0.640 \\
\hline Efficiency $\eta$ & $10.79 \%$ & $10.45 \%$ & $10.27 \%$ \\
\hline
\end{tabular}

Figure S 10. Current density vs. applied potential curves for the best $\left[\mathrm{Cu}(\mathrm{tmby})_{2}\right]^{+1 /+2}$ device employing Y123 dye

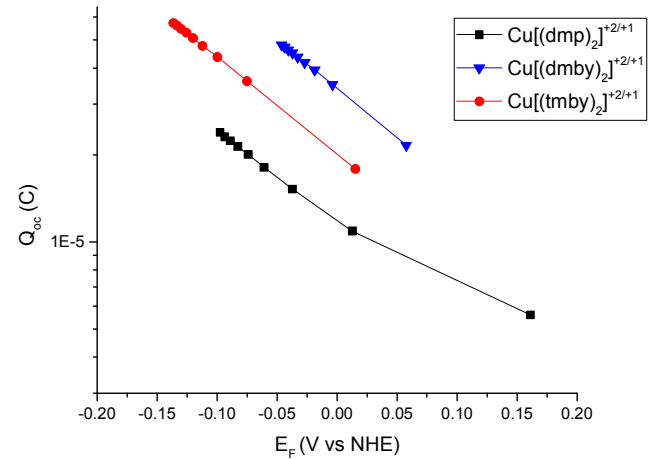

Figure S 11. Charge extraction data obtained for devices with different electrolytes $\left(E_{F, T i O 2}=\right.$ $\left.E_{F, \text { redox }}-V_{o c}\right)$ 


\section{Computed minimum-energy structures of the $\mathrm{Cu}$ complexes in acetonitrile solution}

\section{- $\mathbf{C u}(\mathbf{I})(\mathrm{dmp})_{2}$}

C $\quad 0.000000 \quad 3.437845 \quad 2.717409$

C $\quad 0.000000 \quad 2.813679 \quad 3.938417$

C $\quad 0.000000 \quad 1.409689 \quad 3.998460$

C $\quad 0.000000 \quad 0.718616 \quad 2.772885$

C $\quad 0.000000 \quad 2.673725 \quad 1.535898$

C $\quad 0.000000 \quad 0.677908 \quad 5.225014$

C $0.000000 \quad-0.718616 \quad 2.772885$

C $\quad 0.000000 \quad-1.409689 \quad 3.998460$

C $\quad 0.000000 \quad-0.677908 \quad 5.225014$

$\begin{array}{llll}\text { C } & 0.000000 & -2.813679 & 3.938417\end{array}$

$\begin{array}{llll}\mathrm{H} & 0.000000 & -3.389521 & 4.858127\end{array}$

$\begin{array}{llll}\text { C } & 0.000000 & -3.437845 & 2.717409\end{array}$

$\begin{array}{llll}\text { C } & 0.000000 & -2.673725 & 1.535898\end{array}$

$\begin{array}{llll}\mathrm{H} & 0.000000 & 1.233856 & 6.156661\end{array}$

$\begin{array}{llll}\mathrm{H} & 0.000000 & 4.518995 & 2.645991\end{array}$

$\begin{array}{llll}\mathrm{H} & 0.000000 & 3.389521 & 4.858127\end{array}$

H $\quad 0.000000 \quad-1.233856 \quad 6.156661$

$\mathrm{H} \quad 0.000000 \quad-4.518995 \quad 2.645991$

$\mathrm{N} \quad 0.000000 \quad-1.346931 \quad 1.578023$

$\begin{array}{llll}\mathrm{N} & 0.000000 & 1.346931 & 1.578023\end{array}$

$\begin{array}{llll}\mathrm{Cu} & 0.000000 & 0.000000 & 0.000000\end{array}$

$\begin{array}{llll}\text { C } & 3.437845 & 0.000000 & -2.717409\end{array}$

$\begin{array}{llll}\text { C } & 2.813679 & 0.000000 & -3.938417\end{array}$

C $\quad 1.409689 \quad 0.000000 \quad-3.998460$

$\begin{array}{llll}\text { C } & 0.718616 & 0.000000 & -2.772885\end{array}$

$\begin{array}{llll}\text { C } & 2.673725 & 0.000000 & -1.535898\end{array}$

$\begin{array}{llll}\text { C } & 0.677908 & 0.000000 & -5.225014\end{array}$

$\begin{array}{llll}\text { C } & -0.718616 & 0.000000 & -2.772885\end{array}$

C $\quad-1.409689 \quad 0.000000 \quad-3.998460$

$\begin{array}{llll}\text { C } & -0.677908 & 0.000000 & -5.225014\end{array}$

$\begin{array}{llll}\text { C } & -2.813679 & 0.000000 & -3.938417\end{array}$

$\mathrm{H} \quad-3.389521 \quad 0.000000 \quad-4.858127$

C $\quad-3.437845 \quad 0.000000 \quad-2.717409$

$\begin{array}{llll}\text { C } & -2.673725 & 0.000000 & -1.535898\end{array}$

$\mathrm{H} \quad 1.233856 \quad 0.000000 \quad-6.156661$

H $\quad 4.518995 \quad 0.000000 \quad-2.645991$

H $\quad 3.389521 \quad 0.000000 \quad-4.858127$

$\mathrm{H} \quad-1.233856 \quad 0.000000 \quad-6.156661$

$\mathrm{H} \quad-4.518995 \quad 0.000000 \quad-2.645991$

$\mathrm{N} \quad-1.346931 \quad 0.000000 \quad-1.578023$

$\mathrm{N} \quad 1.346931 \quad 0.000000 \quad-1.578023$

C $\quad 0.000000 \quad 3.324255 \quad 0.194213$

$\mathrm{H} \quad 0.880076 \quad 3.018090 \quad-0.378654$

$\mathrm{H} \quad-0.880076 \quad 3.018090 \quad-0.378654$

$\begin{array}{llll}\mathrm{H} & 0.000000 & 4.410877 & 0.281888\end{array}$

C $\quad 0.000000 \quad-3.324255 \quad 0.194213$

$\mathrm{H} \quad-0.880076 \quad-3.018090 \quad-0.378654$

$\mathrm{H} \quad 0.880076 \quad-3.018090 \quad-0.378654$

H $\quad 0.000000 \quad-4.410877 \quad 0.281888$

$\begin{array}{llll}\text { C } & -3.324255 & 0.000000 & -0.194213\end{array}$

$\mathrm{H} \quad-3.018090 \quad-0.880076 \quad 0.378654$

$\mathrm{H} \quad-3.018090 \quad 0.880076 \quad 0.378654$

$\begin{array}{llll}\mathrm{H} & -4.410877 & 0.000000 & -0.281888\end{array}$

C $\quad 3.324255 \quad 0.000000 \quad-0.194213$

$\mathrm{H} \quad 3.018090 \quad 0.880076 \quad 0.378654$

H $\quad 3.018090 \quad-0.880076 \quad 0.378654$

$\begin{array}{llll}\mathrm{H} & 4.410877 & 0.000000 & -0.281888\end{array}$

\section{- $\mathrm{Cu}(\mathrm{II})(\mathrm{dmp})_{2}$}

$\begin{array}{llll}\text { C } & 0.000000 & 3.447834 & 2.744646\end{array}$

$\begin{array}{llll}\text { C } & 0.000000 & 2.812798 & 3.958769\end{array}$

C $\quad 0.000000 \quad 1.407523 \quad 4.016029$

$\begin{array}{llll}\text { C } & 0.000000 & 0.719345 & 2.790139\end{array}$

$\begin{array}{llll}\text { C } & 0.000000 & 2.692381 & 1.558584\end{array}$

C $\quad 0.000000 \quad 0.677701 \quad 5.242233$

$\begin{array}{llll}\text { C } & 0.000000 & -0.719345 & 2.790139\end{array}$

$\begin{array}{llll}\text { C } & 0.000000 & -1.407523 & 4.016029\end{array}$

$\begin{array}{llll}\text { C } & 0.000000 & -0.677701 & 5.242233\end{array}$

C $\quad 0.000000 \quad-2.812798 \quad 3.958769$

$\mathrm{H} \quad 0.000000 \quad-3.382509 \quad 4.882114$

$\begin{array}{llll}\text { C } & 0.000000 & -3.447834 & 2.744646\end{array}$

$\begin{array}{llll}\text { C } & 0.000000 & -2.692381 & 1.558584\end{array}$

$\mathrm{H} \quad 0.000000 \quad 1.235090 \quad 6.172555$

$\begin{array}{llll}\mathrm{H} & 0.000000 & 4.528909 & 2.680127\end{array}$

$\begin{array}{llll}\mathrm{H} & 0.000000 & 3.382509 & 4.882114\end{array}$

$\mathrm{H} \quad 0.000000 \quad-1.235090 \quad 6.172555$

$\begin{array}{llll}\mathrm{H} & 0.000000 & -4.528909 & 2.680127\end{array}$

$\mathrm{N} \quad 0.000000 \quad-1.367545 \quad 1.607480$

$\begin{array}{llll}\mathrm{N} & 0.000000 & 1.367545 & 1.607480\end{array}$

$\begin{array}{llll}\mathrm{Cu} & 0.000000 & 0.000000 & 0.000000\end{array}$

$\begin{array}{llll}\text { C } & 3.447834 & 0.000000 & -2.744646\end{array}$

$\begin{array}{llll}\text { C } & 2.812798 & 0.000000 & -3.958769\end{array}$

C $\quad 1.407523 \quad 0.000000 \quad-4.016029$

$\begin{array}{llll}\text { C } & 0.719345 & 0.000000 & -2.790139\end{array}$

C $\quad 2.692381 \quad 0.000000 \quad-1.558584$

$\begin{array}{llll}\text { C } & 0.677701 & 0.000000 & -5.242233\end{array}$

C $\quad-0.719345 \quad 0.000000 \quad-2.790139$

$\begin{array}{llll}\text { C } & -1.407523 & 0.000000 & -4.016029\end{array}$

C $\quad-0.677701 \quad 0.000000 \quad-5.242233$

$\begin{array}{llll}\text { C } & -2.812798 & 0.000000 & -3.958769\end{array}$

$\mathrm{H} \quad-3.382509 \quad 0.000000 \quad-4.882114$

$\begin{array}{llll}\text { C } & -3.447834 & 0.000000 & -2.744646\end{array}$

C $\quad-2.692381 \quad 0.000000 \quad-1.558584$

$\mathrm{H} \quad 1.235090 \quad 0.000000 \quad-6.172555$

$\begin{array}{llll}\mathrm{H} & 4.528909 & 0.000000 & -2.680127\end{array}$

H $3.382509 \quad 0.000000 \quad-4.882114$

H $\quad-1.235090 \quad 0.000000 \quad-6.172555$

$\begin{array}{llll}\mathrm{H} & -4.528909 & 0.000000 & -2.680127\end{array}$

$\mathrm{N} \quad-1.367545 \quad 0.000000 \quad-1.607480$

N $\quad 1.367545 \quad 0.000000 \quad-1.607480$

$\begin{array}{llll}\mathrm{C} & 0.000000 & 3.339281 & 0.217511\end{array}$

$\mathrm{H} \quad 0.882124 \quad 3.034279 \quad-0.352811$

$\mathrm{H} \quad-0.882124 \quad 3.034279 \quad-0.352811$

$\begin{array}{llll}\mathrm{H} & 0.000000 & 4.425178 & 0.304528\end{array}$

$\begin{array}{llll}\text { C } & 0.000000 & -3.339281 & 0.217511\end{array}$

$\mathrm{H} \quad-0.882124 \quad-3.034279 \quad-0.352811$

$\mathrm{H} \quad 0.882124 \quad-3.034279 \quad-0.352811$

H $\quad 0.000000 \quad-4.425178 \quad 0.304528$

C $\quad-3.339281 \quad 0.000000 \quad-0.217511$

$\mathrm{H} \quad-3.034279 \quad-0.882124 \quad 0.352811$

$\begin{array}{llll}\mathrm{H} & -3.034279 & 0.882124 & 0.352811\end{array}$

$\begin{array}{llll}\mathrm{H} & -4.425178 & 0.000000 & -0.304528\end{array}$

$\begin{array}{llll}\text { C } & 3.339281 & 0.000000 & -0.217511\end{array}$

$\mathrm{H} \quad 3.034279 \quad 0.882124 \quad 0.352811$

H $3.034279 \quad-0.882124 \quad 0.352811$

H $\quad 4.425178 \quad 0.000000 \quad-0.304528$ 


\begin{tabular}{|c|c|c|c|}
\hline \multicolumn{4}{|c|}{ - $\mathrm{Cu}(\mathrm{I})(\mathrm{dmby})_{2}$} \\
\hline $\mathrm{C}$ & -0.013591 & 3.467448 & 2.622825 \\
\hline $\mathrm{C}$ & -0.043570 & 2.870767 & 3.871470 \\
\hline $\mathrm{C}$ & -0.042513 & 1.489750 & 3.962864 \\
\hline $\mathrm{C}$ & -0.006705 & 0.741330 & 2.791095 \\
\hline $\mathrm{C}$ & 0.012382 & 2.665282 & 1.486393 \\
\hline $\mathrm{C}$ & 0.006705 & -0.741330 & 2.791095 \\
\hline $\mathrm{C}$ & 0.042513 & -1.489750 & 3.962864 \\
\hline $\mathrm{C}$ & 0.043570 & -2.870767 & 3.871470 \\
\hline $\mathrm{H}$ & 0.069296 & -3.476122 & 4.770719 \\
\hline $\mathrm{C}$ & 0.013591 & -3.467448 & 2.622825 \\
\hline $\mathrm{C}$ & -0.012382 & -2.665282 & 1.486393 \\
\hline $\mathrm{H}$ & -0.012627 & 4.545729 & 2.518166 \\
\hline $\mathrm{H}$ & -0.069296 & 3.476122 & 4.770719 \\
\hline $\mathrm{H}$ & 0.012627 & -4.545729 & 2.518166 \\
\hline $\mathrm{N}$ & -0.015822 & -1.328820 & 1.584089 \\
\hline $\mathrm{N}$ & 0.015822 & 1.328820 & 1.584089 \\
\hline $\mathrm{Cu}$ & 0.000000 & 0.000000 & 0.000000 \\
\hline $\mathrm{C}$ & 3.467448 & 0.013589 & -2.622825 \\
\hline $\mathrm{C}$ & 2.870767 & 0.043569 & -3.871470 \\
\hline $\mathrm{C}$ & 1.489750 & 0.042513 & -3.962864 \\
\hline $\mathrm{C}$ & 0.741330 & 0.006704 & -2.791095 \\
\hline $\mathrm{C}$ & 2.665282 & -0.012385 & -1.486393 \\
\hline $\mathrm{C}$ & -0.741330 & -0.006704 & -2.791095 \\
\hline $\mathrm{C}$ & -1.489750 & -0.042513 & -3.962864 \\
\hline $\mathrm{C}$ & -2.870767 & -0.043569 & -3.871470 \\
\hline $\mathrm{H}$ & -3.476121 & -0.069296 & -4.770719 \\
\hline $\mathrm{C}$ & -3.467448 & -0.013589 & -2.622825 \\
\hline $\mathrm{C}$ & -2.665282 & 0.012385 & -1.486393 \\
\hline $\mathrm{H}$ & 4.545728 & 0.012624 & -2.518166 \\
\hline $\mathrm{H}$ & 3.476121 & 0.069296 & -4.770719 \\
\hline $\mathrm{H}$ & -4.545728 & -0.012624 & -2.518166 \\
\hline $\mathrm{N}$ & -1.328820 & 0.015824 & -1.584089 \\
\hline $\mathrm{N}$ & 1.328820 & -0.015824 & -1.584089 \\
\hline $\mathrm{C}$ & 0.035386 & 3.254454 & 0.116349 \\
\hline $\mathrm{H}$ & 0.918121 & 2.915802 & -0.432810 \\
\hline $\mathrm{H}$ & -0.841639 & 2.935030 & -0.453492 \\
\hline $\mathrm{H}$ & 0.045599 & 4.344028 & 0.158628 \\
\hline $\mathrm{C}$ & -0.035386 & -3.254454 & 0.116349 \\
\hline $\mathrm{H}$ & -0.918121 & -2.915802 & -0.432810 \\
\hline $\mathrm{H}$ & 0.841639 & -2.935030 & -0.453492 \\
\hline $\mathrm{H}$ & -0.045599 & -4.344028 & 0.158628 \\
\hline $\mathrm{C}$ & -3.254455 & 0.035393 & -0.116349 \\
\hline $\mathrm{H}$ & -2.935033 & -0.841632 & 0.453493 \\
\hline $\mathrm{H}$ & -2.915801 & 0.918128 & 0.432808 \\
\hline $\mathrm{H}$ & -4.344029 & 0.045608 & -0.158629 \\
\hline $\mathrm{C}$ & 3.254455 & -0.035393 & -0.116349 \\
\hline $\mathrm{H}$ & 2.935033 & 0.841632 & 0.453493 \\
\hline $\mathrm{H}$ & 2.915801 & -0.918128 & 0.432808 \\
\hline $\mathrm{H}$ & 4.344029 & -0.045608 & -0.158629 \\
\hline $\mathrm{H}$ & -0.072425 & 1.012463 & 4.932761 \\
\hline $\mathrm{H}$ & 0.072425 & -1.012463 & 4.932761 \\
\hline $\mathrm{H}$ & 1.012462 & 0.072426 & -4.932760 \\
\hline $\mathrm{H}$ & & & \\
\hline
\end{tabular}

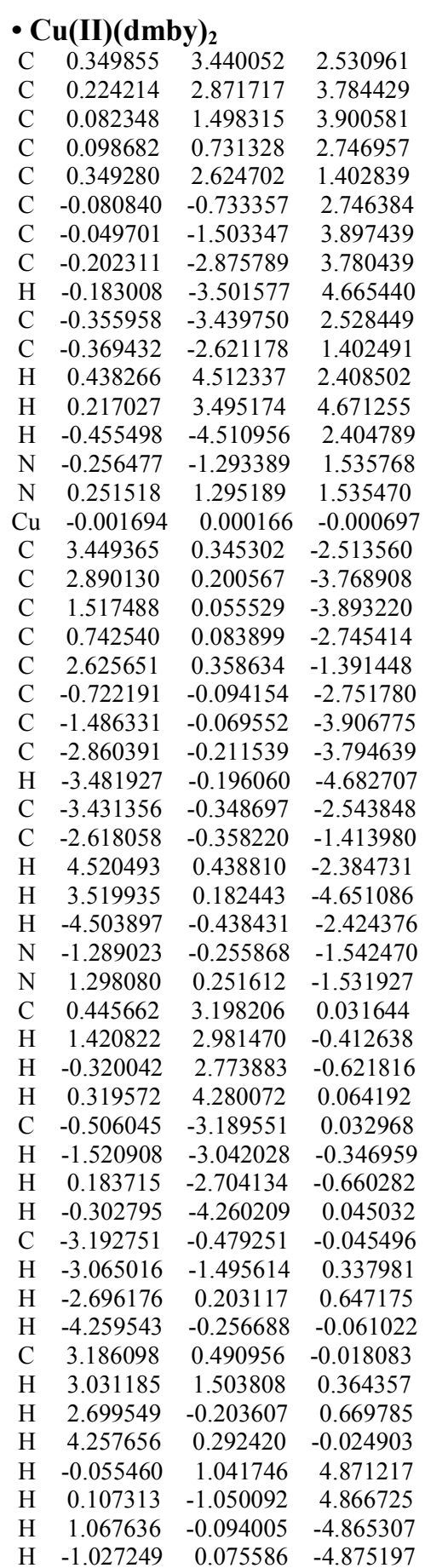




\section{- $\mathbf{C u}(\mathrm{I})(\mathrm{tmby})_{2}$}

$\begin{array}{llll}\text { C } & 0.036726 & 3.459983 & 2.638217\end{array}$

$\begin{array}{llll}\text { C } & 0.054553 & 2.878325 & 3.899316\end{array}$

$\begin{array}{llll}\text { C } & 0.043954 & 1.488068 & 3.964117\end{array}$

$\begin{array}{llll}\text { C } & 0.011759 & 0.742263 & 2.794567\end{array}$

$\begin{array}{llll}\text { C } & 0.012269 & 2.663281 & 1.498838\end{array}$

$\begin{array}{llll}\text { C } & -0.011759 & -0.742263 & 2.794567\end{array}$

$\begin{array}{llll}\text { C } & -0.043954 & -1.488068 & 3.964117\end{array}$

$\begin{array}{llll}\text { C } & -0.054553 & -2.878325 & 3.899316\end{array}$

$\begin{array}{llll}\text { C } & -0.036726 & -3.459983 & 2.638217\end{array}$

$\begin{array}{llll}\text { C } & -0.012269 & -2.663281 & 1.498838\end{array}$

$\begin{array}{llll}\mathrm{H} & 0.043063 & 4.539058 & 2.532690\end{array}$

$\begin{array}{llll}\mathrm{H} & -0.043063 & -4.539058 & 2.532690\end{array}$

$\begin{array}{llll}\mathrm{N} & 0.000000 & -1.327474 & 1.584956\end{array}$

$\begin{array}{llll}\mathrm{N} & 0.000000 & 1.327474 & 1.584956\end{array}$

$\begin{array}{llll}\mathrm{Cu} & 0.000000 & 0.000000 & -0.000021\end{array}$

$\begin{array}{llll}\text { C } & 3.459686 & 0.061585 & -2.638422\end{array}$

$\begin{array}{llll}\text { C } & 2.877510 & 0.077664 & -3.899598\end{array}$

$\begin{array}{llll}\text { C } & 1.487648 & 0.054581 & -3.964225\end{array}$

$\begin{array}{llll}\text { C } & 0.742109 & 0.017909 & -2.794367\end{array}$

$\begin{array}{llll}\text { C } & 2.663425 & 0.031543 & -1.499155\end{array}$

$\begin{array}{llll}\text { C } & -0.742109 & -0.017909 & -2.794367\end{array}$

$\begin{array}{llll}\text { C } & -1.487648 & -0.054581 & -3.964225\end{array}$

$\begin{array}{llll}\text { C } & -2.877510 & -0.077664 & -3.899598\end{array}$

$\begin{array}{llll}\text { C } & -3.459686 & -0.061585 & -2.638422\end{array}$

$\begin{array}{llll}\text { C } & -2.663425 & -0.031543 & -1.499155\end{array}$

$\begin{array}{llll}\mathrm{H} & 4.538755 & 0.072817 & -2.533017\end{array}$

$\begin{array}{llll}\mathrm{H} & -4.538755 & -0.072817 & -2.533017\end{array}$

$\begin{array}{llll}\mathrm{N} & -1.327459 & -0.010811 & -1.585042\end{array}$

$\begin{array}{llll}\mathrm{N} & 1.327459 & 0.010811 & -1.585042\end{array}$

$\begin{array}{llll}\text { C } & -0.000117 & 3.263526 & 0.132693\end{array}$

$\begin{array}{llll}\mathrm{H} & 0.878809 & 2.944717 & -0.434588\end{array}$

$\mathrm{H} \quad-0.880733 \quad 2.932177 \quad-0.424405$

$\begin{array}{llll}\mathrm{H} & -0.006290 & 4.352880 & 0.182234\end{array}$

$\begin{array}{llll}\text { C } & 0.000117 & -3.263526 & 0.132693\end{array}$

$\begin{array}{llll}\mathrm{H} & -0.878809 & -2.944717 & -0.434588\end{array}$

$\mathrm{H} \quad 0.880733 \quad-2.932177 \quad-0.424405$

$\mathrm{H} \quad 0.006290 \quad-4.352880 \quad 0.182234$

C $\quad-3.263721 \quad-0.021061 \quad-0.133011$

$\begin{array}{llll}\mathrm{H} & -2.937960 & -0.896301 & 0.435994\end{array}$

$\begin{array}{llll}\mathrm{H} & -2.939347 & 0.863251 & 0.422346\end{array}$

$\mathrm{H} \quad-4.353091 \quad-0.023441 \quad-0.182523$

$\begin{array}{llll}\text { C } & 3.263721 & 0.021061 & -0.133011\end{array}$

$\begin{array}{llll}\mathrm{H} & 2.937960 & 0.896301 & 0.435994\end{array}$

$\begin{array}{llll}\mathrm{H} & 2.939347 & -0.863251 & 0.422346\end{array}$

$\mathrm{H} \quad 4.353091 \quad 0.023441 \quad-0.182523$

$\begin{array}{llll}\mathrm{H} & 0.062795 & 1.003455 & 4.931853\end{array}$

$\begin{array}{llll}\mathrm{H} & -0.062795 & -1.003455 & 4.931853\end{array}$

$\begin{array}{llll}\mathrm{H} & 1.002954 & 0.067317 & -4.931983\end{array}$

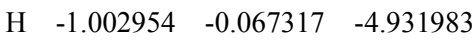

$\begin{array}{llll}\text { C } & 3.703166 & 0.130949 & -5.143933\end{array}$

$\begin{array}{llll}\mathrm{H} & 3.363398 & -0.610497 & -5.871239\end{array}$

$\begin{array}{llll}\mathrm{H} & 3.613389 & 1.112502 & -5.619963\end{array}$

H $\quad 4.757775 \quad-0.045806 \quad-4.928648$

$\begin{array}{llll}\text { C } & -3.703166 & -0.130949 & -5.143933\end{array}$

$\begin{array}{llll}\mathrm{H} & -3.363398 & 0.610497 & -5.871239\end{array}$

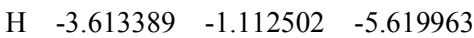

$\begin{array}{llll}\mathrm{H} & -4.757775 & 0.045806 & -4.928648\end{array}$

$\begin{array}{llll}\text { C } & -0.084888 & -3.704031 & 5.144530\end{array}$

$\mathrm{H} \quad 0.775013 \quad-3.476493 \quad 5.780792$

$\begin{array}{llll}\mathrm{H} & -0.983346 & -3.487951 & 5.729866\end{array}$

$\begin{array}{llll}\mathrm{H} & -0.072089 & -4.770060 & 4.914091\end{array}$

$\begin{array}{llll}\text { C } & 0.084888 & 3.704031 & 5.144530\end{array}$

$\begin{array}{llll}\mathrm{H} & -0.775013 & 3.476493 & 5.780792\end{array}$

$\mathrm{H} \quad 0.983346 \quad 3.487951 \quad 5.729866$

H $\quad 0.072089 \quad 4.770060 \quad 4.914091$
- Cu(II)(tmby)

$\begin{array}{llll}\text { C } & 0.178848 & 3.445947 & 2.544675\end{array}$

$\begin{array}{llll}\text { C } & 0.077458 & 2.887729 & 3.810888\end{array}$

$\begin{array}{llll}\text { C } & 0.000000 & 1.498553 & 3.898583 \\ \text { C } & 0.05685 & 0.736614 & 2.74745\end{array}$

$\begin{array}{llll}\text { C } & 0.056865 & 0.736614 & 2.747465\end{array}$

$\begin{array}{llll}\text { C } & 0.225517 & 2.638034 & 1.414190\end{array}$

$\begin{array}{llll}\text { C } & -0.056865 & -0.736614 & 2.747465 \\ \text { C } & 0.00000 & -1.498553 & 3.89883\end{array}$

$\begin{array}{llll}\text { C } & 0.000000 & -1.498553 & 3.898583 \\ \text { C } & -0.077458 & -2.88729 & 3.81088\end{array}$

$\begin{array}{llll}\text { C } & -0.077458 & -2.887729 & 3.810888\end{array}$

$\begin{array}{llll}\text { C } & -0.178848 & -3.445947 & 2.544675\end{array}$

$\begin{array}{llll}\text { C } & -0.225517 & -2.638034 & 1.414190\end{array}$

$\mathrm{H} \quad 0.211680 \quad 4.522040 \quad 2.420956$

$\begin{array}{llll}\mathrm{H} & -0.211680 & -4.522040 & 2.420956\end{array}$

$\begin{array}{llll}\mathrm{N} & -0.193059 & -1.304512 & 1.533762\end{array}$

$\begin{array}{llll}\mathrm{N} & 0.193059 & 1.304512 & 1.533762\end{array}$

$\begin{array}{llll}\mathrm{Cu} & 0.000000 & 0.000000 & 0.002700\end{array}$

$\begin{array}{llll}\text { C } & 3.389933 & 0.651120 & -2.545357\end{array}$

$\begin{array}{llll}\text { C } & 2.844418 & 0.503966 & -3.812727\end{array}$

$\begin{array}{llll}\text { C } & 1.479754 & 0.232791 & -3.900206\end{array}$

$\begin{array}{llll}\text { C } & 0.722788 & 0.153063 & -2.747117\end{array}$

$\begin{array}{llll}\text { C } & 2.588582 & 0.556331 & -1.413219\end{array}$

$\begin{array}{llll}\text { C } & -0.722788 & -0.153063 & -2.747117\end{array}$

$\begin{array}{llll}\text { C } & -1.479754 & -0.232791 & -3.900206\end{array}$

$\begin{array}{llll}\text { C } & -2.844418 & -0.503966 & -3.812727\end{array}$

$\begin{array}{llll}\text { C } & -3.389933 & -0.651120 & -2.545357\end{array}$

$\begin{array}{llll}\text { C } & -2.588582 & -0.556331 & -1.413219\end{array}$

$\begin{array}{llll}\mathrm{H} & 4.450380 & 0.838177 & -2.423065\end{array}$

$\begin{array}{llll}\mathrm{H} & -4.450380 & -0.838177 & -2.423065\end{array}$

$\begin{array}{llll}\mathrm{N} & -1.274330 & -0.329222 & -1.531577\end{array}$

$\begin{array}{llll}\mathrm{N} & 1.274330 & 0.329222 & -1.531577\end{array}$

$\begin{array}{lllll}\text { C } & 0.301585 & 3.230799 & 0.048849\end{array}$

$\begin{array}{llll}\mathrm{H} & 1.299340 & 3.100787 & -0.378770\end{array}$

$\begin{array}{llll}\mathrm{H} & -0.413717 & 2.749637 & -0.622184\end{array}$

$\begin{array}{llll}\mathrm{H} & 0.086083 & 4.298409 & 0.087230\end{array}$

$\begin{array}{llll}\text { C } & -0.301585 & -3.230799 & 0.048849\end{array}$

$\begin{array}{llll}\mathrm{H} & -1.299340 & -3.100787 & -0.378770\end{array}$

$\begin{array}{llll}\mathrm{H} & 0.413717 & -2.749637 & -0.622184\end{array}$

$\begin{array}{llll}\mathrm{H} & -0.086083 & -4.298409 & 0.087230\end{array}$

$\begin{array}{llll}\text { C } & -3.165202 & -0.707687 & -0.046988\end{array}$

$\begin{array}{llll}\mathrm{H} & -2.946002 & -1.700348 & 0.355302\end{array}$

$\begin{array}{llll}\mathrm{H} & -2.742177 & 0.030431 & 0.636842\end{array}$

$\begin{array}{llll}\mathrm{H} & -4.247964 & -0.586620 & -0.075695\end{array}$

$\begin{array}{llll}\text { C } & 3.165202 & 0.707687 & -0.046988\end{array}$

$\begin{array}{llll}\mathrm{H} & 2.946002 & 1.700348 & 0.355302\end{array}$

$\begin{array}{llll}\mathrm{H} & 2.742177 & -0.030431 & 0.636842\end{array}$

$\begin{array}{llll}\mathrm{H} & 4.247964 & 0.586620 & -0.075695\end{array}$

$\begin{array}{llll}\mathrm{H} & -0.121198 & 1.028447 & 4.865992\end{array}$

$\begin{array}{llll}\mathrm{H} & 0.121198 & -1.028447 & 4.865992\end{array}$

$\begin{array}{lllll}\mathrm{H} & 1.025459 & 0.079194 & -4.870466\end{array}$

$\begin{array}{llll}\mathrm{H} & -1.025459 & -0.079194 & -4.870466\end{array}$

$\begin{array}{llll}\text { C } & 3.677227 & 0.626901 & -5.043878\end{array}$

$\begin{array}{llll}\mathrm{H} & 3.490345 & -0.206822 & -5.724998\end{array}$

$\begin{array}{llll}\mathrm{H} & 3.418392 & 1.544617 & -5.581536\end{array}$

$\begin{array}{lllll}\mathrm{H} & 4.740359 & 0.659363 & -4.804332\end{array}$

$\begin{array}{llll}\text { C } & -3.677227 & -0.626901 & -5.043878\end{array}$

$\begin{array}{llll}\mathrm{H} & -3.490345 & 0.206822 & -5.724998\end{array}$

$\begin{array}{llll}\mathrm{H} & -3.418392 & -1.544617 & -5.581536\end{array}$

$\begin{array}{llll}\mathrm{H} & -4.740359 & -0.659363 & -4.804332\end{array}$

$\begin{array}{llll}\text { C } & -0.030798 & -3.733104 & 5.038977\end{array}$

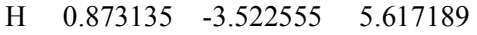

$\begin{array}{llll}\mathrm{H} & -0.884133 & -3.510580 & 5.686145\end{array}$

$\begin{array}{llll}\mathrm{H} & -0.050053 & -4.794801 & 4.792124\end{array}$

$\begin{array}{llll}\text { C } & 0.030798 & 3.733104 & 5.038977\end{array}$

$\begin{array}{llll}\mathrm{H} & -0.873135 & 3.522555 & 5.617189\end{array}$

$\begin{array}{llll}\mathrm{H} & 0.884133 & 3.510580 & 5.686145\end{array}$

$\mathrm{H} \quad 0.050053 \quad 4.794801 \quad 4.792124$ 